\title{
Openness and Restraint: Structure, Discourse, and Contention in Saudi Twitter
}

\section{Citation}

Noman, Helmi, Rob Faris, and John Kelly. 2015. "Openness and Restraint: Structure, Discourse, and Contention in Saudi Twitter." The Berkman Klein Center for Internet \& Society Research Publication No. 2015-16.

\section{Published Version}

https://cyber.harvard.edu/publications/2015/saudi_twitter

\section{Permanent link}

http://nrs.harvard.edu/urn-3:HUL.InstRepos:28552580

\section{Terms of Use}

This article was downloaded from Harvard University's DASH repository, and is made available under the terms and conditions applicable to Other Posted Material, as set forth at http:// nrs.harvard.edu/urn-3:HUL.InstRepos:dash.current.terms-of-use\#LAA

\section{Share Your Story}

The Harvard community has made this article openly available.

Please share how this access benefits you. Submit a story.

Accessibility 
Research Publication No. 2015-16

December 8, 2015

Openness and Restraint:

Structure, Discourse, and Contention in Saudi Twitter

\author{
Helmi Noman \\ Robert Faris \\ John Kelly
}

This paper can be downloaded without charge at:

The Berkman Center for Internet \& Society Research Publication Series: https://cyber.law.harvard.edu/publications/2015/saudi_twitter

The Social Science Research Network Electronic Paper Collection:

Available at SSRN: http://ssrn.com/abstract=2700944

\footnotetext{
23 Everett Street. Second Floor - Cambridge, Massachusetts 02138 $+1617.495 .7547 \cdot+1617.495 .7641$ (fax) • http://cyber.law.harvard.edu • cyber@1aw.harvard.edu
} 


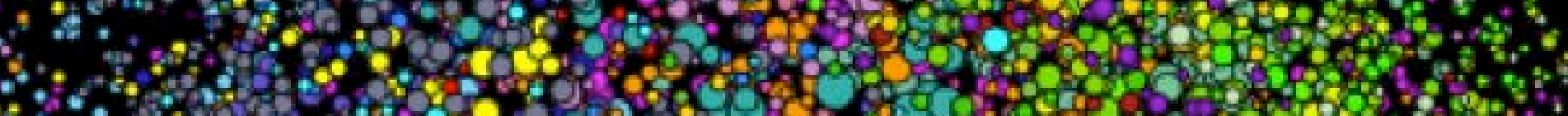
*.

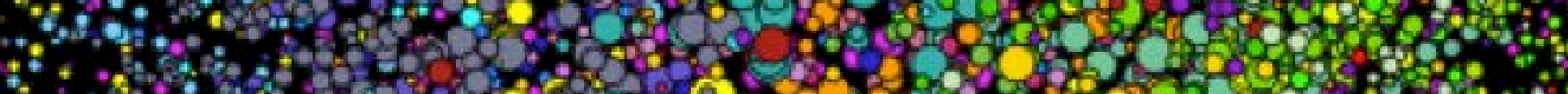

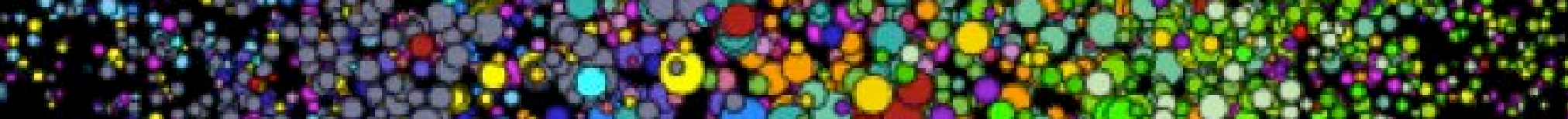

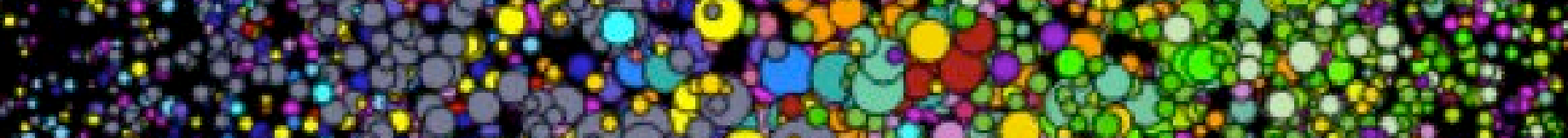

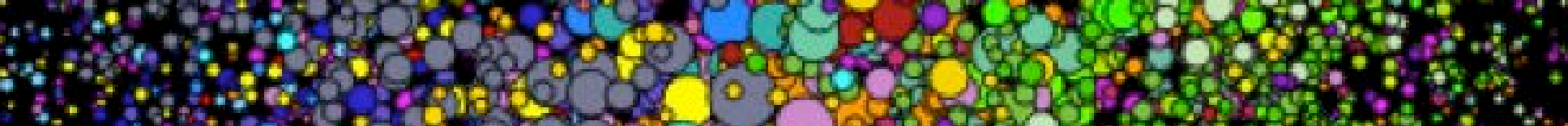

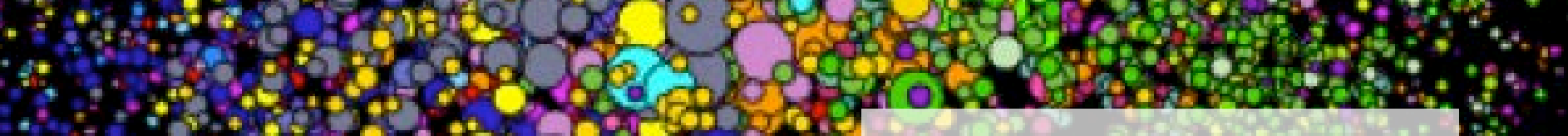

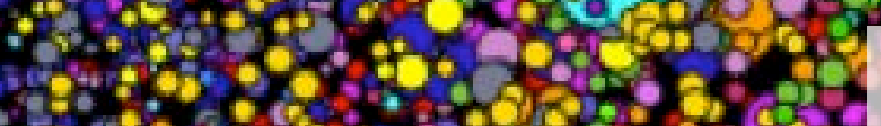
* at

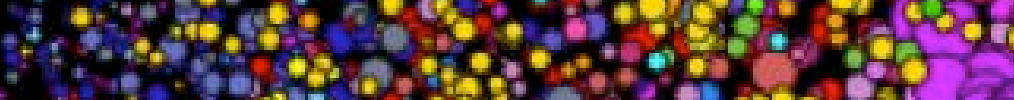

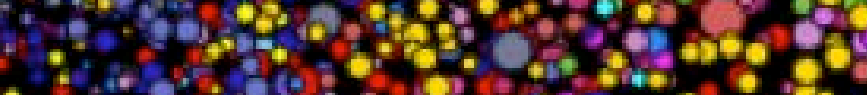

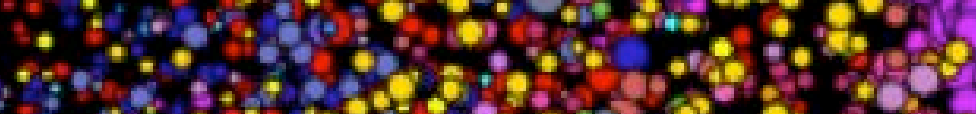

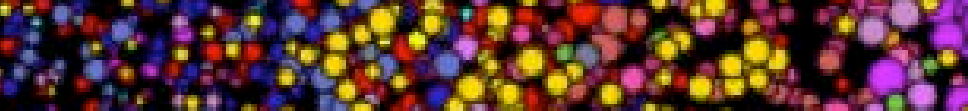

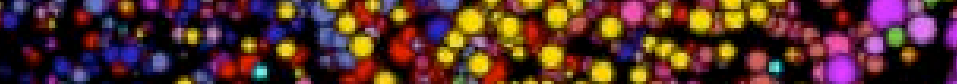

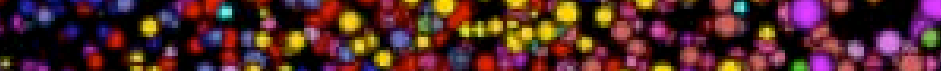

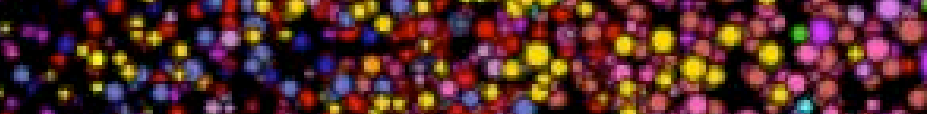
$\because 4$.

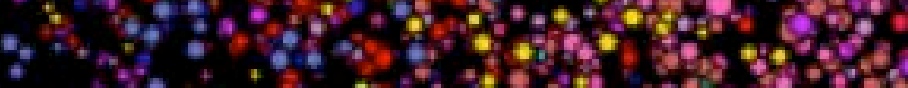

\section{Structure, Discourse,} and Contention in Saudi Twitter

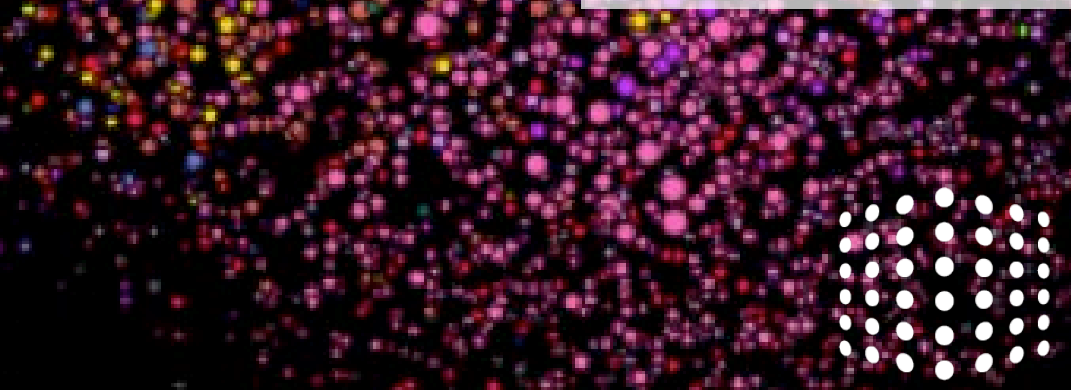


INTERNET MONITOR is a research project to evaluate, describe, and summarize the means, mechanisms, and extent of Internet content controls and Internet activity around the world.

thenetmonitor.org

INTERNET MONITOR is a project of the
Berkman Center for Internet \& Society.
http://cyber.law.harvard.edu

COVER IMAGE

Saudi Twitter Map 
December 2015

\section{Openness and Restraint Structure, Discourse, and Contention in Saudi Twitter}

Helmi Noman

Robert Faris

John Kelly 


\section{ABSTRACT}

In this study, we map and analyze the structure and content of the Saudi Twittersphere and identify the communities that coalesce around different political, religious, social, and cultural topics and viewpoints. This study of the Saudi Twittersphere offers a detailed view of public sentiment and provides insights into the overall structure, discourse, and communities of the network. We look into how users take advantage of the fact that Twitter is an unfiltered media platform to advance their political and social causes. We also examine three case studies centered on issues that received extensive attention on Twitter at the national level during the course of this study.

Twitter opens up public space for Saudi citizens to engage in political and social discourse in a country that heavily restricts political speech, civic engagement, and media freedom. This space is technically accessible for public participation, but is shaped by legal measures regulating objectionable content and fear of confrontation with state policies and social norms. These nontechnical factors that constrain users seem to be behind two online behaviors that we observe on Saudi Twitter: users opt to self-censor their online activities to avoid problematic speech, and many of those who take controversial political stands choose to do so using pseudonyms. Within these constraints, the discourse and communities on Twitter reveal intellectual diversity and social divisions. We are able to see who is most interested in what issues and which topics are debated.

\section{AUTHORS}

HeImi Noman is a Research Affiliate of the Berkman Center for Internet \& Society at Harvard University. His research focuses on Internet censorship in the Middle East and North Africa; exploring the impact of information and communication technologies on the Arab information societies; how the use of the Internet defies the social and political structures; and the potential systemic changes cyberspace can bring to real space in the Arab region.

Robert Faris is the Research Director at the Berkman Center for Internet \& Society at Harvard University. His recent research has been focused on developing and applying methods for studying the networked public sphere.

John Kelly is the founder and CEO of Graphika, Inc, and a long-time Research Affiliate of the Berkman Center for Internet \& Society at Harvard University.

\section{ACKNOWLEDGEMENTS}

The authors gratefully acknowledge the support and help of the many people who contributed to this research. Rebekah Heacock Jones was instrumental in producing this paper: editing the paper, designing the layout, managing the team of researchers, and providing excellent feedback on early drafts of the paper. Sonya Yan Song carried out the data gathering and analysis related to profile images and user location. Muira McCammon and Jenny Shore provided superb research assistance. Jonathan Zittrain and Urs Gasser offered invaluable guidance, support, and advice. We are deeply grateful to Ahmed Al Omran for providing feedback and advice and owe special thanks to the several people who reviewed this paper and offered feedback but have chosen to remain anonymous.

The data and maps used in this paper are courtesy of Graphika, Inc. 


\section{INTRODUCTION}

Just a few years ago, the Saudi blogosphere was teeming with activity. Participants debated politics, religion, sports, and culture; posted poetry; and chronicled their personal lives. Saudi bloggers formed the second largest network in the region, second only to Egypt. ${ }^{1}$ Today, the Kingdom has virtually disappeared from the blogosphere. ${ }^{2}$ In the meantime, the use of Twitter has flourished in Saudi Arabia. The Kingdom reportedly now has the highest percentage of active Twitter users among its online population. ${ }^{3}$ Twitter, along with Facebook and other social media platforms, has supplanted blogging as the principal venue for Saudis to participate in the networked public sphere.

In this study, we map and analyze the structure and content of the Saudi Twittersphere and identify the communities that coalesce around different political, religious, social, and cultural topics and viewpoints. This study of the Saudi Twittersphere offers a detailed view of public sentiment and provides insights into the overall structure, discourse, and communities of the network. We look into how users take advantage of the fact that Twitter is an unfiltered media platform to advance their political and social causes. We also examine three case studies centered on issues that received extensive attention on Twitter at the national level during the course of this study.

\section{OVERVIEW}

Twitter opens up public space for Saudi citizens to engage in political and social discourse in a country that heavily restricts political speech, civic engagement, and media freedom. This space is technically accessible for public participation, but is shaped by legal measures regulating objectionable content and fear of confrontation with state policies and social norms. These nontechnical factors that constrain users seem to be behind two online behaviors that we observe on Saudi Twitter: users opt to self-censor their online activities to avoid problematic speech and many of those that take controversial political stands choose to do so using pseudonyms. Within these constraints, the discourse and communities on Twitter reveal intellectual diversity and social divisions. We are able to see who is most interested in what issues and which topics are debated.

The Saudi Twittersphere contains a wide spectrum of opinions and activities, including political and social commentary; political dissidence and criticism of the monarchy; media professionals discussing and promoting their products; religious preachers spreading Islamic messages; Syrian revolution supporters; sports officials and fans tweeting about local soccer teams; users relying heavily on pre-selected content tweeting automation tools; and users tweeting popular quotes, banal messages, and observations of daily life.

Religion, football, and politics are the topics that draw the most attention on Twitter in Saudi Arabia. Of the 36 clusters identified in this study, 21 are drawn together around discussion of these three issues. Political dissidents, critics of the monarchy, and supporters of political causes and militancy in Syria and Iraq provide opinions and perspectives not found in traditional media. Religion and conservative political views serve as the centers of gravity in Twitter discussions and as topics of intense debate. The principal areas of contention are alternative visions of conservative ideology and the legitimacy of religious viewpoints. Accounts of religious figures are by far the most followed on the map, and they fuel heated debate on religiously contentious issues. There is also open criticism of the government, especially on issues of corruption and quality of public services. 
While some voices advocate for women's rights, including mobility and driving, others campaign to keep the status quo. Secular and progressive causes are not prominent in these networks.

The dissident community on Twitter takes advantage of the fact that Twitter is not blocked in the Kingdom. Many dissidents participate in the discourse using pseudonyms. This practice is most likely rooted in concerns over government surveillance of their online activities and fears of the repercussions of being identified. Many of the websites that are shared in posts and inform the discussion of dissidents are blocked in the Kingdom.

Users who defend the Saudi government do not appear in discrete clusters but are instead distributed across various clusters; they are most visible in the clusters that focus on religion. These clusters include clerics and academics dedicated to Islamic studies who are affiliated with Saudi religious institutions.

\section{THE RISE OF TWITTER IN SAUDI ARABIA}

The adoption of Twitter, Facebook, and other social media platforms has displaced blogging activity around the world. Nowhere has this shift been more rapid than in the Middle East. ${ }^{4}$ In Saudi Arabia, it is estimated that $32 \%$ of the population of Internet users are active on Twitter. ${ }^{5}$ As in other countries, a significant portion of this growth might be attributed to the high level of mobile Internet usage; mobile Internet penetration is estimated to be $60 \%$ in the Kingdom. ${ }^{6}$

Other social media platforms such as Facebook and Instagram are widely used in Saudi Arabia and contribute to the online public discourse. It is unclear whether these other platforms occupy significantly different niches in the public sphere and how their reach and influence compare to Twitter. The growth of Twitter in particular has prompted many to seek explanations for its widespread adoption. One crowdsourced attempt to answer this question took place on Twitter itself using the hashtag \#Why_did_Twitter_succeed_in_Saudi_Arabia and its Arabic equivalent. BBC Monitoring, a service that monitors trending hashtags, captured some of the answers provided on Twitter, which included: the ability for users to say on Twitter what they cannot say offline for fear of suppression and the idea that Twitter is "the only democracy" available to Saudis by helping everyone talk: "the rich and the poor, the prince and the ordinary citizen."7

Many have noted that Saudi Twitter users engage in conversations that would not have taken place so prominently and publicly in the past. On Twitter, unprecedented open criticism of the Saudi royal family, government corruption, and social neglect has become commonplace. The prominent Saudi cleric Salman al-Awda is quoted as saying: "Twitter has revealed a great frustration and a popular refusal of the current situation." " Others have suggested that social media might constitute a "socially progressive force.",

Given the dearth of channels for political engagement and civic participation in Saudi Arabia outside of officially sanctioned venues, social media offer an alternative space for political expression and civil society organizing. Political parties are banned in the Kingdom. ${ }^{10}$ Civil society is underdeveloped due in part to the laws that restrict the activities and funding of civil society organizations while state administrative measures effectively ban independent civic action. Thus, most of the civil society organizations in the Kingdom are government-affiliated. ${ }^{11}$ 


\section{SOCIAL MEDIA AND THE ONLINE REGULATORY ENVIRONMENT}

The Internet and media environment in Saudi Arabia has long been tightly regulated; these efforts now extend into restrictions on social media. Because of concerns over the impact of an open Internet, the government did not allow broad deployment of the Internet in Saudi Arabia until a filtering system was put in place and the state felt confident it could control the content users could access. Strong Internet filtering was a prerequisite for Internet deployment in the Kingdom. ${ }^{12}$ The censors filter content on social and religious grounds as well as oppositional political websites and websites of human rights organizations. The censorship regime thus "mirrors broader attempts by the state to repress opposition and promote a single religious creed." "13

The social media environment in Saudi Arabia is a highly contested space, and activity on Twitter is of great concern to the government. Speaking at a symposium in March 2015, a Saudi official from the Ministry of Interior described an increase of offensive tweets, which he described as being of eight types:

1. offending the rulers;

2. dissenting against the monarchy;

3. expressing attitudes of class superiority;

4. igniting regional prejudices;

5. offending clerics;

6. promoting intellectual deviation;

7. promoting extremism; and

8. destabilizing security. ${ }^{14}$

Recognizing such threats, there are many forces that are working to shape and constrain public discourse in digital space. For the government of Saudi Arabia, regulating a highly popular social media platform that falls outside of its jurisdiction represents a conundrum. The Minister of Information admitted in February 2013 that his ministry and other government agencies follow activities on Twitter, but said that monitoring the platform is difficult because of the large number of users. ${ }^{15}$

The Saudi authorities have used vague provisions of a 2007 anti-cybercrime law to step up their crackdown on lawyers and activists who peacefully criticize the government on Twitter. ${ }^{16}$ For example, in 2014, three lawyers were sentenced to prison terms for criticizing the Justice Ministry on Twitter, and a liberal women's rights advocate was detained for tweets promoting women's right to drive and criticizing religious figures. ${ }^{17}$ Moreover, the government criminalizes a broad range of activities by labeling them as acts of terrorism. This includes questioning the Kingdom's religious foundation, "unsettling the social and national fabric... or any actions that touch the unity and stability of the Kingdom under any reason and in any form." ${ }^{18}$ Government officials have also requested information from Twitter on users. In the period between January and June 2015, there were 93 requests to Twitter for account information. Twitter reports that they turned over information for $69 \%$ of these requests. ${ }^{19}$

Saudi religious leaders have objected to the use of Twitter, saying it is used to attack Islam. In 
October 2014, for example, the Kingdom's Grand Mufti criticized Twitter and labeled it as "the repository of scourge and evil and the source of lies and falsehoods." ${ }^{20}$ In addition, state-sponsored religious police known as the Commission for the Promotion of Virtue and Prevention of Vice and religiously motivated activists monitor the Internet for objectionable content and offenders, organize counter-speech campaigns to mobilize society against intellectual movements considered liberal, and compromise websites perceived as objectionable and Twitter accounts of Saudi activists over their allegedly anti-Islam views. ${ }^{21}$

As recently as 2011, Saudi Arabia selectively blocked Twitter accounts containing objectionable content. ${ }^{\mathrm{A}}$ This appears to have ended. We tested local access to all of the Twitter account pages from within the Saudi Twittersphere map that have political dissident content as well as various accounts that have sensitive content and found no evidence that any of the pages are blocked. Given that many websites affiliated with the Twitter accounts are blocked in Saudi Arabia, it is likely that the censors in Saudi Arabia do not have the capability in their current filtering infrastructure to block access to specific Twitter account pages without blocking Twitter entirely since Twitter introduced HTTPS as its default connection in 2011. ${ }^{22}$ Blocking the platform in its entirety would come at a high political cost. Twitter has thereby become a new world for Saudi citizens: a very popular unfiltered social media platform. ${ }^{\mathrm{B}}$

Efforts to limit content on Twitter relevant to social and political life in Saudi Arabia continue by other means. If identified by the government, individuals who engage in objectionable activities online may be subject to arrest and prosecution, backed by a restrictive legal framework. Religious information campaigns are common on Saudi Twitter, targeting individuals who offend conservative religious values. Additionally, religious hack tivists have claimed credit for compromising the Twitter accounts of liberal thinkers.

The range of restrictions undoubtedly influences the discourse and communities that emerge in the Twittersphere. The virtual public sphere that has emerged on Saudi Twitter, which we describe in the following sections, is the result of these complex dynamics: the opinions and perspectives of tens of thousands Saudi Twitter users swayed by state, religious, and private actors.

\section{THE CHALLENGE OF MILITANT ACCOUNTS}

Twitter accounts related to terrorist groups such as the Islamic State (IS) and Al-Qaeda pose a special challenge to the Saudi authorities, as to the world. This has prompted efforts to counter the reach and influence of militants online. The Sakina Campaign for Dialogue, a Saudi program supervised by Ministry of Religious Affairs, aims to challenge and refute extreme ideologies by engaging in online discourse. ${ }^{23}$ The campaign examined Twitter accounts of Saudis who support such groups and, based on the analysis of 200 Twitter accounts and hashtags related to IS and Al-

\footnotetext{
A We found in August 2011 that Saudi Arabia blocked access to the account pages of Wael Ghonim, an Egyptian Internet activist and founder of the "We Are All Khaled Said" Facebook page, and Gamal Eid, an Egyptian human rights activist and lawyer who often posts tweets critical of the human rights record in Saudi Arabia.

B Facebook is also no longer subject to filtering of individual accounts. There are reports from as late as 2012 of Saudi censors blocking individual Facebook pages with objectionable content. See, for example, Freedom House, "Saudi Arabia - Freedom on the Net 2012," https:// freedomhouse.org/report/freedom-net/2012/saudi-arabia. Our tests show no evidence that those pages are still blocked. Facebook introduced seare browsing by default in 2013. See Facebook, "Secure browsing by default," https://www.facebook.com/notes/facebook-engineering/secure-browsing-bydefault/10151590414803920.
} 
Qaeda in Saudi Arabia, found a "dangerous movement" organized by Saudis supporting the militant groups on Twitter. ${ }^{24}$ The campaign director said an average of 90 tweets per minute (129,600 per day) call for violence, to join terrorist groups, to attack others verbally or physically, or to destabilize security. The group reports that a campaign it conducted in April 2014 to influence the views of IS supporters had "produced zero results," but the success rate to influence the views of users who have militant ideology has later improved.

The Saudi government continues to explore and introduce additional means to control activities on Twitter in an attempt to address the challenges raised by objectionable content there. In March 2015, for example, security specialists, academics, and religious clerics held a symposium titled "The social and security dimensions of social networks" under the patronage of the Kingdom's Deputy Crown Prince (who also serves as Minister of Interior) to map out how the country and the other Gulf states can protect themselves from what the participants called the dangers of social networks. ${ }^{25}$ The symposium produced ten recommendations to "protect Saudi Arabia from Twitter":

1. Establish electronic surveillance centers to prevent and remove extreme content on social media networks;

2. Establish multilingual moderate Islamic online presences that have international appeal;

3. Encourage clerics to join social media and interact with the youth;

4. Establish a unified law center to legally pursue offensive Twitter users locally and abroad;

5. Establish an Arab Gulf-wide media center to spread facts and rapidly respond to and refute rumors on social media;

6. Encourage celebrities who have moderate outlooks and many followers on Twitter to advance national unity and to warn against deviated opinions;

7. Enact laws to cope with crimes committed on social media networks;

8. Implement more restrictive measures to prevent the spread of rumors in Saudi Arabia; and

9. Monitor the organizations which people receive information from; and

10. Introduce a special system to hold those who spread rumors responsible. ${ }^{26}$

\section{OBJECTIVES AND METHODS}

The analysis in this report is based on a mixed methods research protocol that includes qualitative content analysis supported and guided by algorithmically drawn network maps and a diverse set of quantitative metrics calculated for each of the clusters in the network. This methodological approach to this study follows similar efforts in the past to map online networks that correspond to particular geographic areas. $^{27}$

The principal objective of this study is to describe accurately Twitter activity in Saudi Arabia within the context of active censorship of political speech online and off and restrictions on media, civil society activism, and political action. To help make order of this rich, complex, and diverse media landscape, we employ social network mapping techniques that generate network maps of Twitter accounts based on the follow relationships between users. The first step is generating a network map of Saudi Twitter accounts based on the relationships between users. The network structure is visualized using a physics model layout algorithm (Fruchterman-Rheingold), overlaid with colors representing each account's assignment to a group based on a clustering of network relationships. 
The resulting network map and structures that emerge reflect the individual decisions of Twitter users to follow other users, and the work of the clustering algorithm that transforms these follow relationships into segments. Qualitative human judgment is subsequently used to interpret the results, but the generation of the maps is based primarily on algorithms that translate the relationships between the accounts in a network structure.

In the visualization, the size of each node reflects the number of followers from the network to that account. The location of each node relative to the others is based on the collective follow decisions of all of the nodes in the network. Accounts that are linked by a follow relationship are pulled together as though by a spring or force of gravity. Densely interconnected network neighborhoods "bunch up" in the map. In this way, one can think of the map as a picture of the pattern of influence and information flow in the network.

The location of nodes on the map is based on follow relationships and therefore reflects longer term stable relationships. Drawing a map based on mentions and retweets would produce a map based in larger part on shorter term interests and influenced more by the content of tweets within the period in which data is collected.

A clustering algorithm assigns each node in the map to a particular cluster, which are represented by different colors. These clusters are based on outward facing attention so that clusters are populated by nodes with a common outlook as determined by the accounts that they follow, mention, retweet, and reply to, and the URLs they include in tweets.

A variety of metrics are calculated to help researchers understand and describe the contours and structures of the map. These metrics provide a quantitative measure of which activities occur proportionately more often in each cluster compared to the others, including:

- Twitter accounts followed

- Twitter accounts mentioned, retweeted, and replied to within a timeframe

- URLs cited in tweets

- Words used, including bigrams and trigrams (pairs and triples)

- Countries, cities, and other locations mentioned in user profiles

Researchers apply labels to each of the clusters based on a review of this data. These labels are not meant to categorize each account within a given cluster but rather offer concise shorthand descriptions for the various clusters. Each of the accounts within each of the clusters offers a unique perspective. For many of the accounts within a cluster, the cluster label offers a good summary of the primary focus and general orientation of the account; for other accounts, the cluster label does not strongly capture the interests and views of the user.

Determining the accounts that populate the map is based on a multistage process for collecting relevant accounts and removing nodes that are less connected to the core network. The mapping starts with a seed set of accounts compiled by researchers. ${ }^{C}$ This set is expanded by adding all of the

C The seed sets, typically 100 or more accounts, are hand-curated lists of Twitter accounts. The accounts that are collected are restricted to those that are easily recognized as part of the targeted country or community. The lists are based in part on the domain-specific knowledge of experts and users embedded in the community of users, in part on 
followers of the seeds, and then reduced by removing all accounts with no activity over the prior 90 days and accounts with fewer than a minimum number of followers (100, in this case). The network of connections between these accounts is analyzed, and a k-core analysis is used to find the most connected accounts. Inclusion in the network is based on three core criteria: accounts must be active; accounts must meet a minimum threshold of links with other accounts in the network, whether following or followed by other accounts; and accounts must have at least one follower from within the network. The final map, which includes 11,699 nodes, therefore includes all the accounts that receive a minimum threshold of attention from the network and removes the accounts with relatively fewer followers in the network. This produces a map that is both rich in detail and resolution while being of a tractable size for quantitative and qualitative analysis.

The themes and communities discussed in this report are based on the structure, clusters, and content that appear in this map of the most highly connected accounts. Removing the peripheral and less prominent accounts may reduce somewhat the range of views and ideas represented in the map such that the issues and communities discussed are not necessarily inclusive or representative of the entire Saudi Twittersphere. Alternative viewpoints and interests of less prominent accounts may not be captured in this report. We do not believe that this detracts in any way from the analysis and observations in this study, which focus on the major clusters in the network and topics of frequent discussion.

In addition to the network mapping and associated content analysis, we estimated the location of the users found in this network map and categorized the profile pictures based upon a manual review of the accounts. The location of users is inferred from the longitude and latitude data where available; these coordinates were included for approximately $37 \%$ of the users in the network. Where this data was not available, we relied instead on user provided location. Approximately $23 \%$ of users fell into this category. The rest did not provide location information or used an ambiguous or broad location or a metaphor. As described in a later section, profile pictures were placed into 13 categories. The location of users and the use of different profile pictures help to explain the composition of the clusters and the variation between them.

\section{NETWORK COMMUNITIES}

In the following sections, we describe the 36 clusters (Table 1) that appear in the network mapping. For many of the clusters, there are significant similarities and overlap with other clusters in the issues that garner attention and the perspectives of the participants. We use these similarities to group the clusters in the narrative description that follows.

\begin{tabular}{|c|l|l|}
\hline GROUP & CLUSTER & DESCRIPTION \\
\hline $\begin{array}{c}\text { POLITICS, } \\
\text { SOCIAL, } \\
\text { BUSINESS, AND } \\
\text { ECONOMY }\end{array}$ & Politics \& Social & $\begin{array}{l}\text { Journalists, public figures, and private citizens commenting on local } \\
\text { political and social issues and events as well as major news and events in } \\
\text { the region. Indudes mild criticism of government policies. }\end{array}$ \\
\cline { 2 - 3 } RELIGION- & Business \& Economy & $\begin{array}{l}\text { Media and citizens discussing business and economy, trade, and the job } \\
\text { market. Economic grievances discussed in this duster. }\end{array}$ \\
\hline
\end{tabular}

following links from a starting set, and in part on web searches for relevant accounts. Each seed set indudes accounts representative of the political, social, and cultural issues in the country. 


\begin{tabular}{|c|c|c|}
\hline \multirow[t]{4}{*}{ FOCUSED } & & in this duster. \\
\hline & Religious Preaching & $\begin{array}{l}\text { Islamic religious studies academics and preachers with proactive public } \\
\text { preaching activities online and on Islamic TV channels. Cluster is vocal in } \\
\text { support of the Saudi monarchy. }\end{array}$ \\
\hline & Islam & $\begin{array}{l}\text { A mixture of religious academics, preachers, and users from various } \\
\text { backgrounds posting educational messages and commentary on political } \\
\text { and social issues from an Islamic perspective. Cluster is vocal in criticizing } \\
\text { Saudi liberal intellectuals and entertainers. }\end{array}$ \\
\hline & $\begin{array}{l}\text { Religious Automated } \\
\text { Tweeting }\end{array}$ & $\begin{array}{l}\text { Mostly accounts using free pre-selected content Twitter automation } \\
\text { services posting Quranic verses, Islamic sayings, and quotes. }\end{array}$ \\
\hline \multirow{3}{*}{ MEDIA-CENTRIC } & Religious Media (2) & $\begin{array}{l}\text { Media professionals and entertainers from religiously conservative TV } \\
\text { channels as well as fans of religious media content discussing and } \\
\text { disseminating media messages that emphasize religious values. }\end{array}$ \\
\hline & General Media & $\begin{array}{l}\text { Saudi TV journalists, media outlets from general and broad content TV } \\
\text { channels, and fans sharing and commenting on TV programming, } \\
\text { induding Western entertainment content. }\end{array}$ \\
\hline & $\begin{array}{l}\text { YouTube Content } \\
\text { Producers }\end{array}$ & $\begin{array}{l}\text { Saudi comedians, actors, and creative producers who produce professional } \\
\text { content, mostly social satire, for their YouTube channels. }\end{array}$ \\
\hline \multirow{3}{*}{$\begin{array}{c}\text { POLITICAL } \\
\text { DISSIDENTS, } \\
\text { MILITANTS, PRO- } \\
\text { SYRIAN } \\
\text { REVOLUTION }\end{array}$} & $\begin{array}{l}\text { Political Dissidents \& } \\
\text { Regional Militancy }\end{array}$ & $\begin{array}{l}\text { Political dissidents, many of whom use pseudonyms opposing the Saudi } \\
\text { monarchy and demanding political reform. Indudes several accounts of } \\
\text { individuals self-described as Saudis belonging to or supporting militant } \\
\text { groups in Iraq and Syria. }\end{array}$ \\
\hline & Political Dissidents & $\begin{array}{l}\text { Political opponents, many using pseudonyms, who question the legitimacy } \\
\text { of the Saudi monarchy, allege corruption, and demand reform. }\end{array}$ \\
\hline & $\begin{array}{l}\text { Regional Pro-Syrian } \\
\text { Revolution }\end{array}$ & $\begin{array}{l}\text { Saudi and Arab religious and political figures and regional journalists } \\
\text { commenting on regional affairs with strong support for the revolution } \\
\text { against the Syrian government. }\end{array}$ \\
\hline SPORTS & Sports Clusters (8) & $\begin{array}{l}\text { Sports dusters populated by sports officials, fans, and journalists discussing } \\
\text { local sports issues, primarily related to soccer dubs and the national soccer } \\
\text { team. }\end{array}$ \\
\hline $\begin{array}{l}\text { GENERAL SOCIAL } \\
\text { CONTENT }\end{array}$ & $\begin{array}{l}\text { General Social Content } \\
\text { Clusters ( } 7)\end{array}$ & $\begin{array}{l}\text { Clusters with limited original content and more retweeting of religious } \\
\text { texts, proverbs, banal daily observations, and popular regional and global } \\
\text { content. }\end{array}$ \\
\hline \multirow{3}{*}{$\begin{array}{l}\text { ENTERTAINMENT } \\
\text { \& PERSONAL }\end{array}$} & Regional Showbiz (2) & $\begin{array}{l}\text { Singers, actors, TV personalities, celebrities, and journalists from Saudi } \\
\text { Arabia and the Arab world posting broad media content with regional } \\
\text { appeal. }\end{array}$ \\
\hline & $\begin{array}{l}\text { Cooking, Fashion \& } \\
\text { Health }\end{array}$ & Users sharing food recipes, fashion design tips, and health advice.. \\
\hline & Personal Diaries & $\begin{array}{l}\text { Users posting personal diary-type reflections and personal comments on } \\
\text { social, entertainment, and sports events. }\end{array}$ \\
\hline \multirow{3}{*}{ REGIONAL } & Kuwaiti Politics & $\begin{array}{l}\text { Media, politicians, and religious figures from Kuwait discussing local and } \\
\text { regional political issues and current affairs. }\end{array}$ \\
\hline & Egyptian Politics & $\begin{array}{l}\text { Politicians, journalists, and activists from Egypt commenting on local and } \\
\text { regional political issues. }\end{array}$ \\
\hline & $\begin{array}{l}\text { Regional \& } \\
\text { International } \\
\text { Politicians \& Media } \\
\end{array}$ & $\begin{array}{l}\text { Politicians and media outlets from the region and Western countries. Not } \\
\text { conversational. }\end{array}$ \\
\hline MIXED & Mixed & $\begin{array}{l}\text { Mixed accounts of individuals and institutions with diverse interests } \\
\text { induding religion, sports, politics, entertainment, media, and social media } \\
\text { marketing. No specific themes emerge in this duster. }\end{array}$ \\
\hline
\end{tabular}




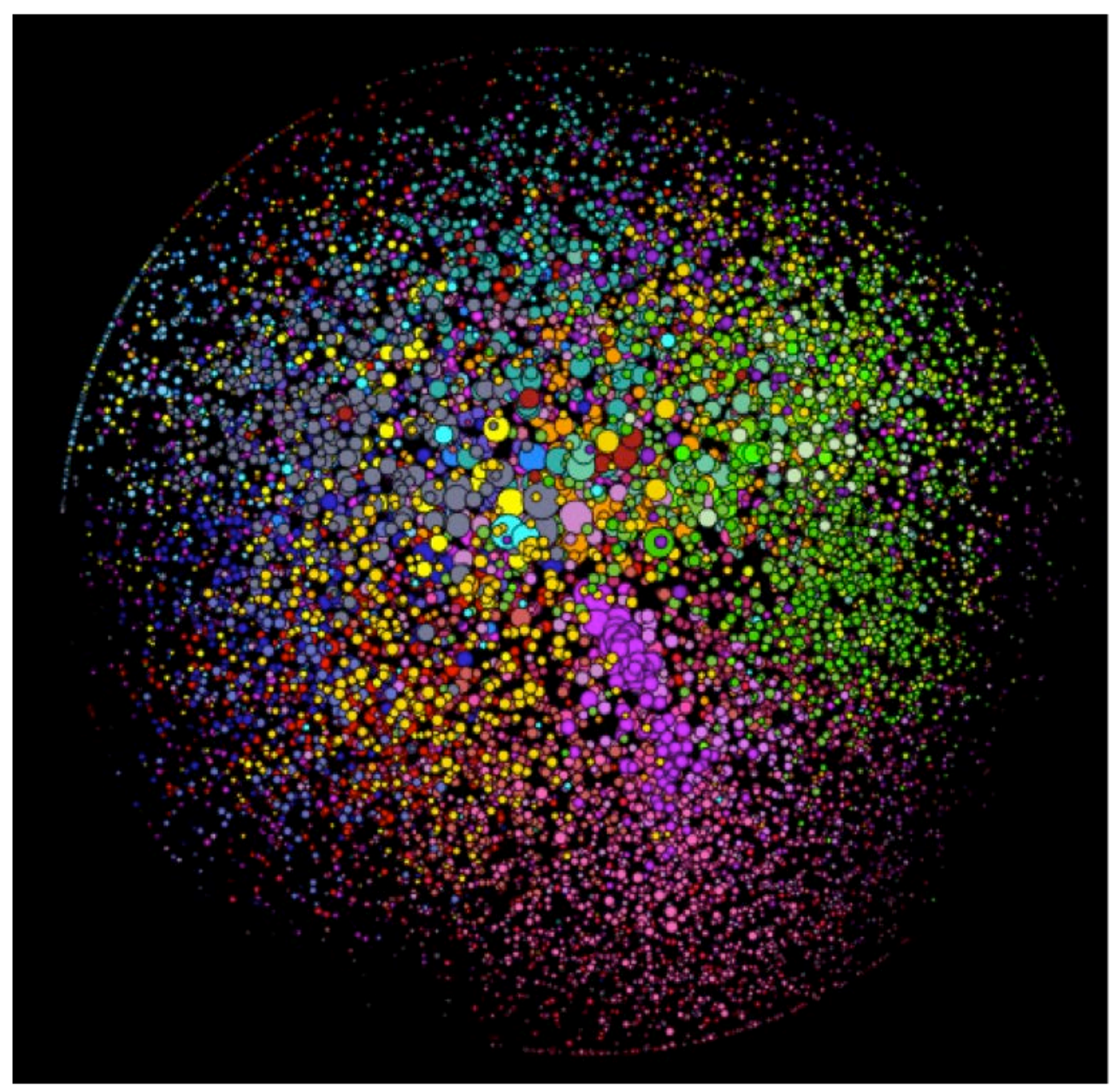

FIGURE 1. SAUDI TWITTER MAP 


\section{POLITICS, SOCIAL, BUSINESS, AND ECONOMY CLUSTERS}

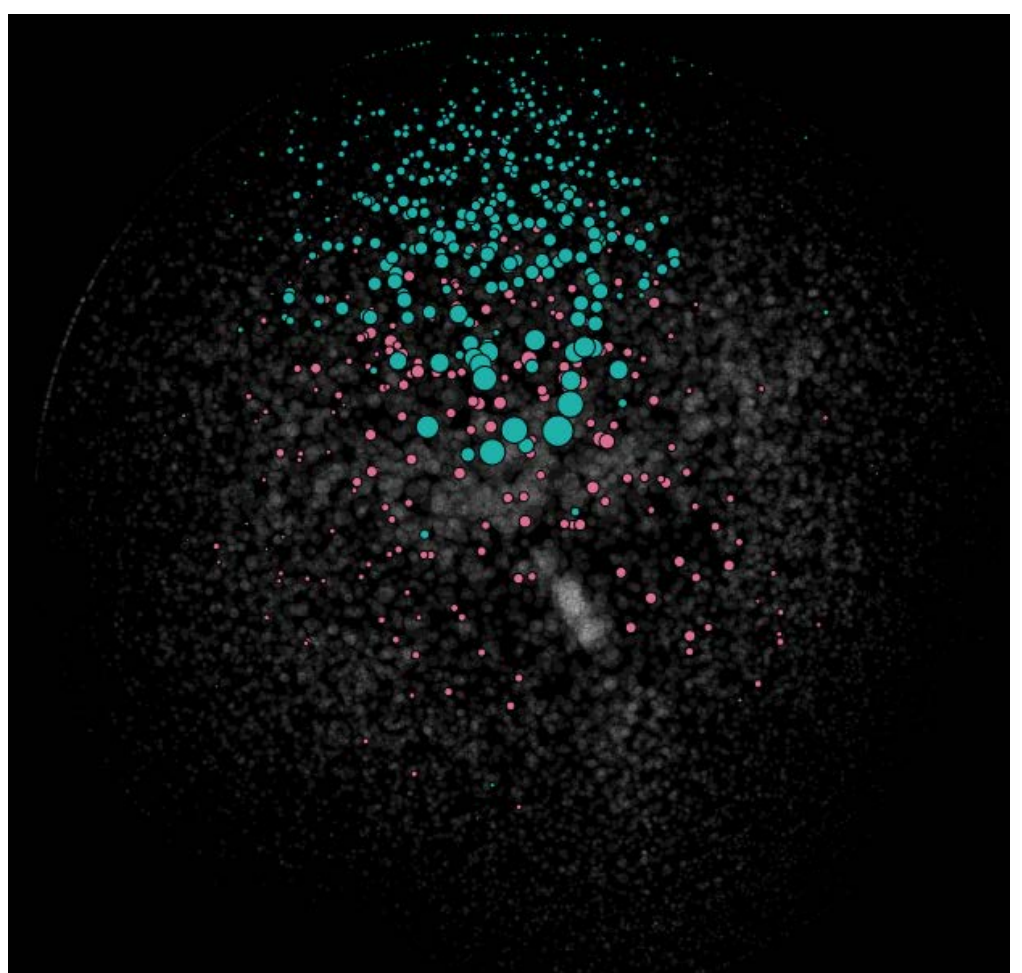

FIGURE 2. POLITICS, SOCIAL, BUSINESS, AND ECONOMY CLUSTERS (POLITICS AND SOCIAL IN AQUAMARINE; BUSINESS AND ECONOMY IN PINK)

The Politics \& Social cluster is populated by Saudi journalists, public figures, and private citizens commenting on Saudi political and social issues and events as well as major news and events in the region. The posts are sometimes critical of Saudi government policies relevant to housing and employment, and public services such as health and education. Tweets also comment on local and regional media stories. Though some of the comments are strongly critical of the government policies, they generally do not amount to political dissidence, and the denunciation is not leveled at the monarchy or royal family. Use of critical cartoons to highlight inefficiency of the government public services is common in this cluster.

The news sources used by this cluster are mostly of local news websites (e.g., Al-Jazirah, ${ }^{28} \mathrm{Okaz}$ AlYoum, ${ }^{29}$, Al-Madina, ${ }^{30}$ and Al-Sharq ${ }^{31}$. The cluster also uses regional Saudi-owned media including Al-Hayat, ${ }^{32}$ Al-Sharq Alawsat, ${ }^{33}$ and the Al-Arabia TV news website. ${ }^{34}$ In addition, the cluster frequently cites Western media websites including The Washington Post, The Daily Mail, The Independent, Huffington Post, Forbes, The Guardian, BBC, and CNN. Users in this cluster also commonly follow websites of human rights organizations such as Amnesty International and Human Rights Watch. Others websites used by this cluster include Times of Israel, the citizen media community Global Voices, Foreign Policy, and the website of the Internet Movie Database. 


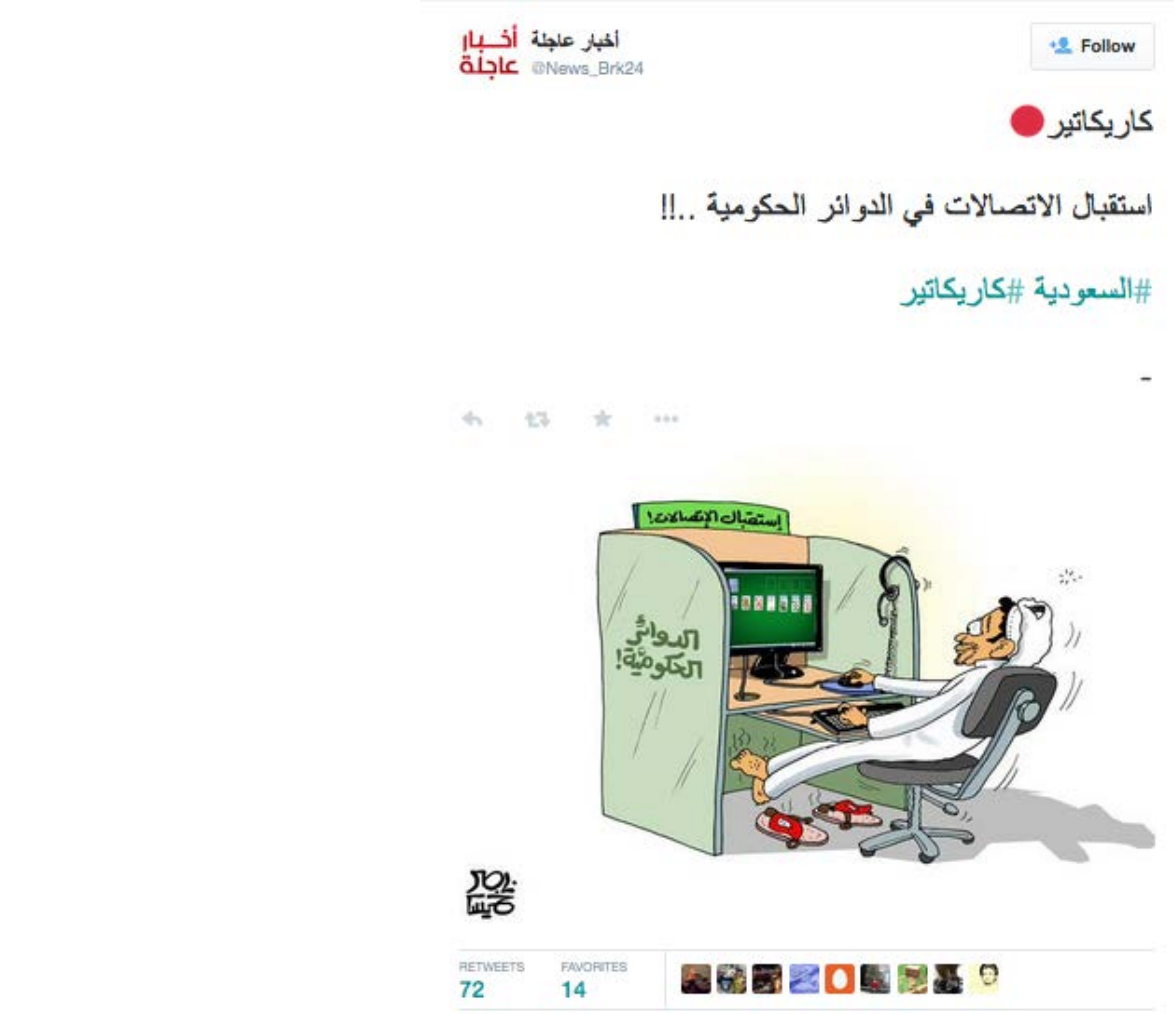

FIGURE 3. AN EXAMPLE OF A CRITICAL CARTOON DISSEMINATED IN THE POLITICS \& SOCIAL CLUSTER: A GOVERNMENT EMPLOYEE PLAYING SOLITAIRE ON THE COMPUTER INSTEAD OF ANSWERING CALLS FROM CITIZENS. ${ }^{35}$

The Business and Economy cluster is comprised of Saudi media and citizens tweeting about general local news reports. The focus of this cluster is the economy, trade, the job market, and the stock market. Accounts dedicated to economic grievances appear in this cluster. For example, the account Teachers' Rights (@teacher_rights) serves as an online advocacy group on many issues raised by Saudi teachers related to salaries and allowances, as well as other issues such as fair geographical distribution of teachers, and sometimes issues of particular concern to Saudi female teachers such as transportation to and from schools in a country that does not allow women to drive. The account has over 176,000 followers and does not have names associated with it. The account offers an email address for teachers to submit their grievances and complaints and tries to bring these grievances to the attention of the Saudi media and officials by addressing tweets to their Twitter handles. Other campaigns that emerge in this cluster are related to unemployment and the government program that aims to "Saudize" the workforce, or replace expatriates with Saudi employees. The discussion on this issue often addresses the challenges associated with this program, such as the higher wages expected by Saudi citizens. Discussion often addresses how the unemployment rate among female Saudi citizens is much higher than among their male counterparts because of the social restrictions and norms in the Kingdom. Using the hashtag \# البطالة_تدق_ناقوس_الخطر (unemployment rings alarm bells), the campaign asserts that unemployment among Saudis has reached a dangerous level.

The URLs shared by this cluster are mostly from local media reporting on local economy, trade, and the stock exchange (e.g., http://www.mubasher.info, http://www.tadawul.com.sa/, and http://www.hawamer.com/). 


\section{RELIGION-FOCUSED CLUSTERS}

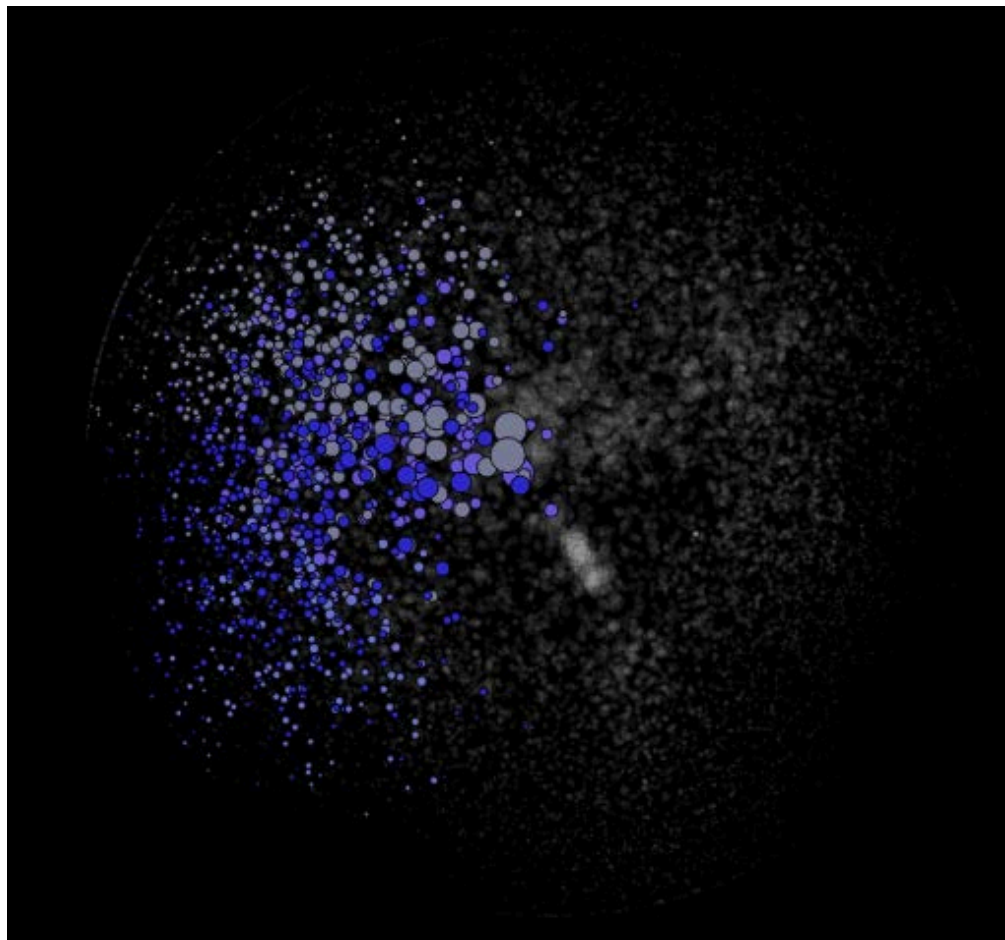

FIGURE 4. RELIGION-FOCUSED CLUSTERS

(RELIGIOUS ACADEMICS; RELIGIOUS PREACHING; ISLAM; RELIGIOUS AUTOMATED TWEETING)

Four religion-themed clusters emerged on the map. Religious Academics is comprised mostly of Saudi academics in religious studies from various Saudi Sharia schools. The discourse in this cluster is centered around academically oriented Islamic issues and uses many Islamic reference and encyclopedic websites. ${ }^{36}$ Though not a predominant theme, users in this cluster show support for the Saudi monarchy and often refute arguments of the political opponents, usually on religious bases; discussion about the importance of obeying the rulers as a religious mandate is not uncommon. ${ }^{37}$ The users often discuss support of the Syrian revolution as an Islamic duty, but at the same time they question and debate the activities of the militant groups there. The cluster uses websites that provide news on the armed conflict in Syria. ${ }^{38}$

The Religious Preaching cluster is populated mostly by Islamic religious studies academics, preachers, and activists. Unlike the Religious Academics cluster, the sheikhs in this cluster have active public preaching activities and have proactive outreach programs on Islamic TV channels and on the Internet, especially on YouTube. Arguments in support of the Saudi monarchy also appear in this cluster. The Islam cluster is a mixture of religious academics, preachers, and users from various backgrounds tweeting personal religious thoughts and Islamic educational messages and commenting on political and social issues from an Islamic perspective. Most of the accounts promote religious conservatism and are often critical of those whom they consider to be Saudi liberal intellectuals and entertainers. A fourth cluster, Religious Automated Tweeting, consists mostly of accounts using pre-selected religious content Twitter automation services. Content appearing in this cluster includes Quranic verses, prophetic sayings, quotes from classic religious 
books, and popular sayings from Muslim religious scholars. The automated tweeting services used in this cluster are free and can be pre-scheduled to post selected messages. An example is the account (a)AAlbsri, which tweets Quranic verses using the service http://qurani.tv/.

Members of the Religion Focus network heavily use religious and religiously oriented online resources pertaining to Salafi Islam, such as the websites of the influential Salafi clerics Ibn Othaimeen ${ }^{39}$ and Bin Baz. ${ }^{40}$ The collective adherence to Salafism by these users, many of whom are academics at local educational institutions and active clerics and preachers, is consistent with the government official religious policy that sanctions the Salafi ideology. In December 2011, then Saudi Crown Prince, deputy premier, and Minister of Interior asserted that "Saudi Arabia would continue to follow the Salafist ideology" and "denounced those who create doubts about this moderate Islamic ideology and link it with terrorism and extremism." ${ }^{41}$ It is noteworthy that this community does not use online resources blocked in the Kingdom. The fact that users in this community are more likely to defend and argue for the monarchy indicates a possible relationship between their religious alignment and support of Kingdom's policies.

\section{MEDIA-CENTRIC CLUSTERS}

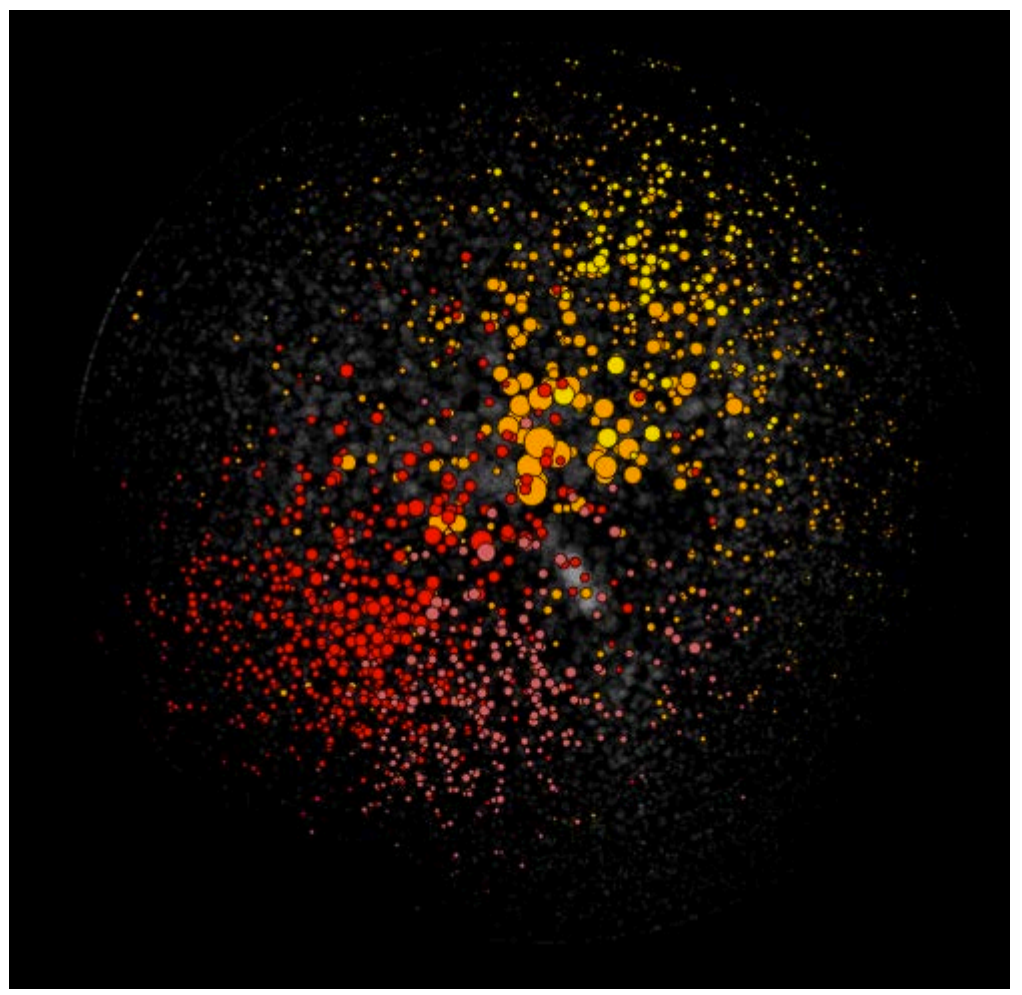

FIGURE 5. MEDIA-CENTRIC CLUSTERS

(GENERAL MEDIA IN ORANGE; YOUTUBE PRODUCERS YELLOW; RELIGIOUS MEDIA 1 RED; RELIGIOUS MEDIA 2 LIGHT RED)

Four media clusters appear in the map. Two of these clusters (Religious Media 1 \& 2) form around religious perspectives and represent an Islamic media community populated mainly by media professionals and entertainers working for religiously conservative TV channels such as Bedaya TV, Almajd TV, and the children's TV channel Semsem TV. Fans of religious media content also populate the clusters. The accounts discuss and disseminate media messages that emphasize religious 
values and post video clips from their TV and YouTube channels. Most of the media and artistic productions shared in these clusters notably use no music, the use of which is considered prohibited by some conservative Muslim scholars, nor do they feature women. Materials produced and shared by the two clusters do include content of general nature such as love, sports, and entertainment, but often with an Islamic tone. Online resources used by these clusters include websites of the TV stations with which the users are affiliated (e.g., almajdtv.tv) and websites on Islam (e.g., islamway.net). YouTube and Instagram are heavily used. URLs of Western media do not appear in these clusters.

The General Media cluster is populated by many Saudi TV journalists and media outlets from general and broad TV channels such as the private Saudi-owned entertainment TV channels MBC Groups and the Rotana Groups' TV channels, whose portfolio includes music, film, and series production. Also in this cluster are some journalists and media professionals who self-identify as liberals. Fans of certain programs and shows also populate this cluster. Few cluster members share and discuss content from the TV channels, especially American movies and television programming. In addition to local news websites, the cluster members use the website of MBC TV Group ${ }^{42}$ as well as Western media websites such as The New York Times and the Daily Mail. YouTube and Instagram are heavily used by this cluster.

The YouTube Content Producers cluster is a community of Saudi comedians, actors, and creative producers who produce professional content, mostly social satire, for their YouTube channels. The YouTube channels receive high traffic from Saudi Arabia and beyond, and have gained international media attention. ${ }^{43}$ The video sharing websites YouTube and Vimeo are among the top used tools by this community, which also uses local news websites such as $\mathrm{Okaz}^{44}$ and Alwatan ${ }^{45}$ as well as regional media such as Al-Arabia TV and Western media such as BBC and Forbes Magazine. The community also uses the websites of Amazon, Global Voices, the Internet Movie Database, and the website of MBC TV Group.

The different preferences for online resources in the media clusters reflect the varying tendencies and comfort with information needs; the Religious Media clusters use online resources that are heavily relevant to and match the community's general religious identity, and there is virtually no use of wide or broad media resources from the Arab world or the Western countries. In contrast, the clusters General Media and YouTube Content Producers use a wide range of Western media websites and websites containing progressive content, which match their liberal approach to media programming and content production. 


\section{POLITICAL DISSIDENTS, REGIONAL MILITANCY, \& PRO-SYRIAN REVOLUTION CLUSTERS}

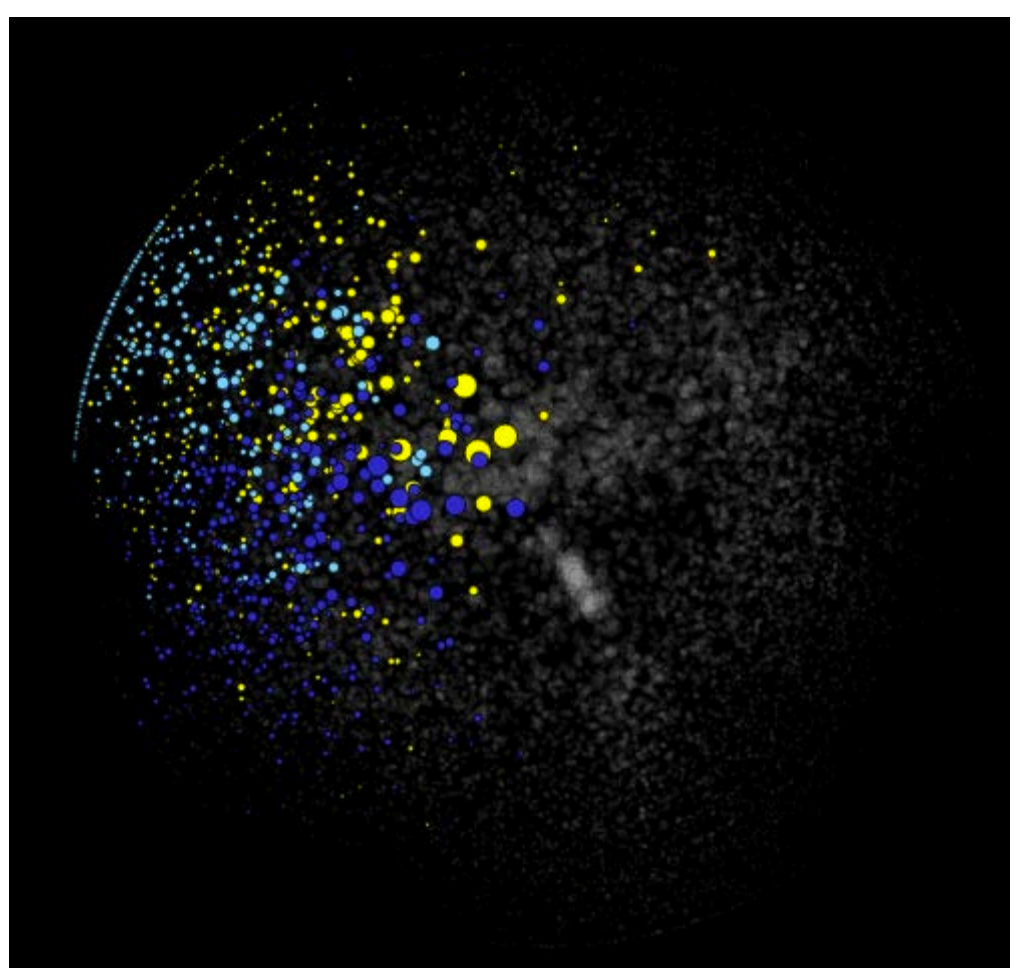

FIGURE 6. POLITICAL DISSIDENTS, SYRIA-FOCUSED, AND REGIONAL MILITANCY CLUSTERS (PRO-SYRIAN REVOLUTION IN YELLOW; POLITICAL DISSIDENTS IN DARK BLUE; POLITICAL DISSIDENTS \& REGIONAL MILITANCY IN LIGHT BLUE)

The Political Dissidents \& Regional Militancy cluster is populated by Saudi political dissidents opposing the Saudi monarchy. Some of the accounts in this cluster use obvious Arabic pseudonyms; others are public figures such as Saad Al-Faqih, a Saudi political dissident living in exile in the United Kingdom. Criticism is centered around what they call the Kingdom's policy alignment with the West; its "hostility" towards political Islam; and what they describe as lack of political reform in the Kingdom. The cluster sympathizes with what they describe as political prisoners in the Kingdom, many of whom are Islamists, and campaigns for their release. The cluster's overall narrative on the political reform stems from Islamic perspectives rather than secular outlooks; the discussion does not promote separation of state and religion or reference secular principles as the basis of the demands.

The cluster includes a few accounts of individuals self-described as Saudis supporting the militant groups in Iraq and Syria or claiming to be members of such militant groups. Twitter suspended and removed most of these accounts during the course of this study.

Some accounts in this cluster focus almost entirely on what they describe as political prisoners in the Kingdom. One such account introduces itself as an association of the political prisoners' families and states its objectives as disseminating reports and news about the Kingdom's human rights records and organizing advocacy initiatives and developing proactive outreach programs concerning human rights in general, and Saudi political prisoners in particular. ${ }^{46}$ Another account is affiliated with an organization called Alqst, which is self-described as an independent non-governmental organization that advocates for human rights and monitors and documents alleged violations in the 
Kingdom. ${ }^{47}$ Such accounts try to crowdsource reports of alleged political or religious torture and to disseminate reports of violations to international anti-torture advocates.

The political dissidents use URLs of websites containing content critical of the Saudi monarchy and the royal family, while militants use websites affiliated with or supportive of militant groups. We tested $^{\mathrm{D}}$ accessibility to these URLs from Saudi Arabia and found the following are blocked:

\begin{tabular}{|l|l|}
\hline BLOCKED SITE & DESCRIPTION \\
\hline www.tawhed.ws & $\begin{array}{l}\text { Tawhid and Jihad forum. Discourse on forum is primarily on Islamic doctrine and } \\
\text { Jihad. }\end{array}$ \\
\hline www.dawaalhaq.com & $\begin{array}{l}\text { A news portal self-described as an "independent service not related to any group } \\
\text { or organization.” Its news and views focus on militant groups in Syria and Iraq. }\end{array}$ \\
\hline nokbah.com & A militant forum. \\
\hline www.jarchive.net & A militant forum. \\
\hline diala99.wordpress.com & A blog about militant groups. \\
\hline shahamat-arabic.com & A militant forum about Afghanistan. \\
\hline muslimcaptives.wordpress.com & A blog about individuals described as Muslim political prisoners and captives. \\
\hline www.shaghor.com & A forum about militant groups in Syria. \\
\hline sheikh-atiyah.nokbah.org & A militant forum. \\
\hline ahmadalmashari.blogspot.nl & A blog containing Saudi dissident content. \\
\hline www.hanein.info & A militant forum. \\
\hline www.fajer.cc & A militant radio station. \\
\hline asrararabiya.com & $\begin{array}{l}\text { A news portal publishing what it calls “Arab secrets," some of which are about } \\
\text { Saudi Arabia. }\end{array}$ \\
\hline mroamaz7.wordpress.com & A blog critical of the Saudi monarchy. \\
\hline www.tarhuni.org & A blog containing artides about what it calls political prisoners in Saudi Arabia. \\
\hline
\end{tabular}

TABLE 2. BLOCKED SITES SHARED BY THE POLITICAL DISSIDENTS \& REGIONAL MILITANCY CLUSTER.

The cluster users cite a variety of news and information sources, including international media such as Reuters, BBC, CNN Arabic; regional media such as Aljazeera ${ }^{48}$ and Alhayat ${ }^{49}$; and Islamic websites that provide news and information about Islam. ${ }^{50}$

This cluster is the only one found to link to US government websites: the website of the US Department of State ${ }^{51}$ and another government website that provides information about the US and US foreign policy. ${ }^{52}$ Other notable websites cited by this cluster are Global Voices and Amnesty International. The only Saudi government news source referenced by this cluster is that of the government newspaper Um Al-Qura. ${ }^{53}$ Both YouTube and Facebook are heavily used in this cluster.

The Political Dissidents cluster is populated mainly by Saudi political opponents questioning the legitimacy of the Saudi monarchy and discussing what they allege as the Kingdom's political and financial corruption. Cluster members demand the introduction of a constitution and public participation in governance and public affairs. This community of dissidents campaigns for the release of Islamist political prisoners and tweets news from their family and friends. Many of the accounts in this cluster use pseudonyms. The overall discourse addresses the issue of reform from

D Test was conducted remotely using a public VPN on Internet service provider STC. 
an Islamic point of view. Tweets of the whistleblower account @Mujtahidd, which often leaks documents alleging corruption in the royal family, are popular in this cluster.

This cluster heavily uses the WikiLeaks website and websites and blogs critical of the Saudi monarchy. We tested access to these URLs from Saudi Arabia and found that seven of the most commonly cited sources are blocked in the Kingdom. The blocked URLs are:

\begin{tabular}{|l|l|}
\hline BLOCKED SITE & DESCRIPTION \\
\hline mroamaz7.wordpress.com & A blog critical of the Saudi monarchy. \\
\hline w3idub.wordpress.com & A blog with political opposition content. \\
\hline ahmadalmashari.blogspot.nl & A blog with Saudi dissident content. \\
\hline www.taqadoumiya.net & $\begin{array}{l}\text { A Tunisian news and views portal that covers Saudi } \\
\text { political issues. }\end{array}$ \\
\hline asrararabiya.com & $\begin{array}{l}\text { A news portal publishing what it calls “Arab secrets," } \\
\text { some of which are about Saudi Arabia }\end{array}$ \\
\hline malekmuteb.com & A political parody site. \\
\hline www.tarhuni.org & $\begin{array}{l}\text { A blog containing articles about what it calls political } \\
\text { prisoners in Saudi Arabia. }\end{array}$ \\
\hline
\end{tabular}

TABLE 3. BLOCKED SITES SHARED BY THE POLITICAL DISSIDENTS CLUSTER.

This cluster uses a number of local news portals, ${ }^{54}$ regional news websites, ${ }^{55}$ and international news websites such as The Guardian, France24, BBC, and CNN Arabic. Amnesty International's website is also used by this cluster. The only Saudi government website used by the cluster is that of Ministry of Commerce and Industry. ${ }^{56}$

The two dissident clusters seem to be privacy-conscious and concerned about possible surveillance; the URL for the online security and anonymity tool Tor appears among the ones they use. They also use the online publishing tool http://justpaste.it, which enables users to post texts and images anonymously without the need for prior registration using an email account.

The Regional Pro-Syrian Revolution cluster is populated by accounts of Saudi and Arab religious figures, a few parliament members from Kuwait, and journalists and media outlets from the Arab region. Discussion in this cluster is about regional affairs, but the common theme is its explicit support for the revolution against the Syrian government. The cluster has a strong religious tone and includes prominent Islamists from the region such as Yusuf Al Qaradawi, the intellectual leader of the Muslim Brotherhood. The cluster uses a sectarian narrative on the war in Syria, presenting the conflict as primarily an issue of Sunni citizens revolting against a largely Shiite regime. It is critical of Iran and Hezbollah for supporting the Syrian government, and refers to the Syrian government, Iran, and Hezbollah in hashtags using religiously derogatory terms. Online resources used by this cluster include many websites covering the Syrian revolution ${ }^{57}$ as well as regional and international media news websites such as Aljazeera TV, Russia Today in Arabic, ${ }^{58}$ and France24. The website of the Israeli newspaper Haaretz also appears among the online resources used by this cluster. Also used in this cluster is the live video streaming service Bambuser, ${ }^{59}$ known to be have been used by Syrian activists to broadcast their activities. ${ }^{60}$ 


\section{SPORTS CLUSTERS}

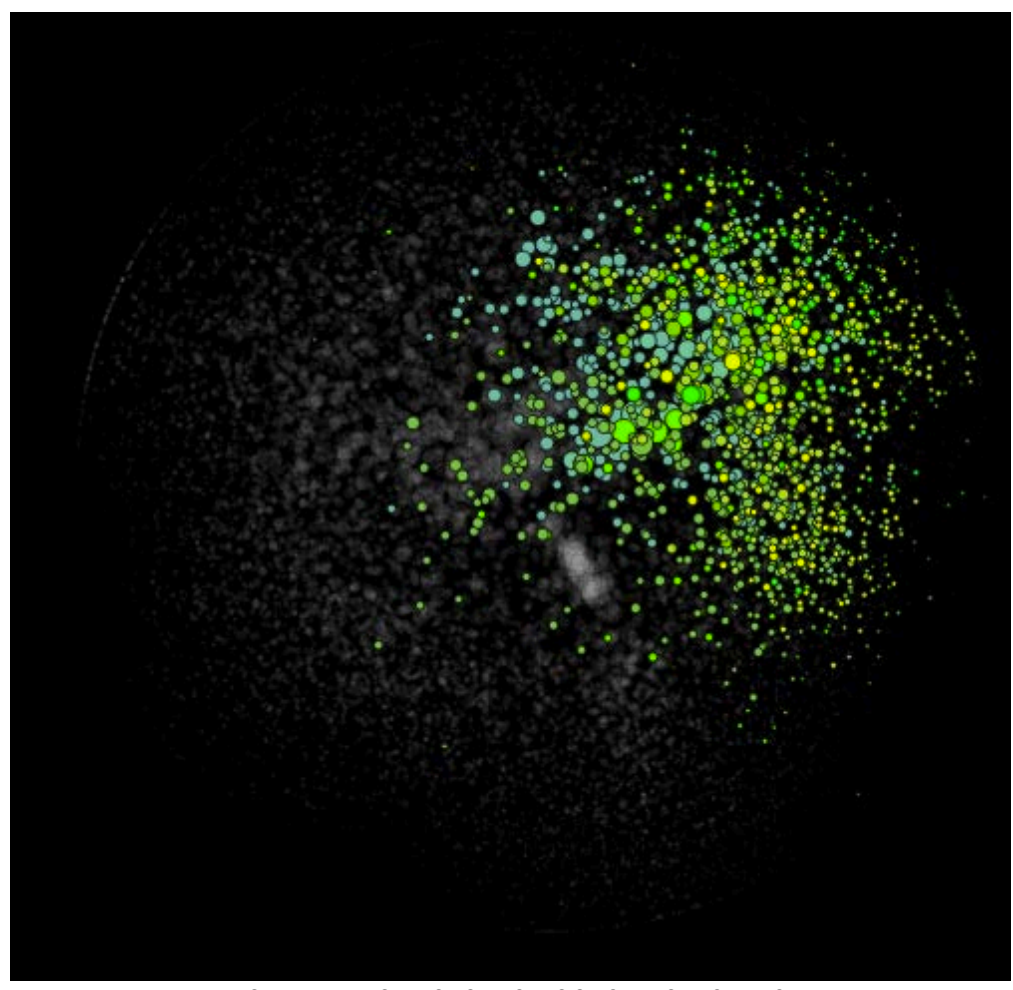

FIGURE 7. EIGHT SPORTS-FOCUSED CLUSTERS

Eight sports clusters appeared in the map. They are populated by sports officials, fans, and journalists. The clusters discuss local sports issues, especially soccer club competitions and the national soccer team. Two of these sports clusters do not focus on a particular team (Sports 1 and Sports 2). Three of the clusters are dominated by officials and fans of the Al Hilal Football Club. Backers of the Al Ittihad Football Club, the Al Nasser Football Club, and the Al Ahli Football Club each form their own cluster. The tweets also debate and protest some policies introduced by sports officials. One example is sports officials banning fans from wearing shorts in football stadiums, an issue that generated intense discussion by fans. Many did not welcome the new rule, saying fans should be allowed to wear what they wish as long as it does not violate social norms and that dress codes imposed in airports and government buildings should not be applied to football stadiums. One tweet said: "Funny rules: banning fans from entering stadiums wearing shorts under the pretext of violating social norms. As if the players in the pitch cover their heads." Another issue often raised by journalists in the sports clusters is the greater enthusiasm shown by fans for local teams at the expense of the national team, as fewer fans attend national team matches. 


\section{GENERAL SOCIAL CONTENT CLUSTERS}

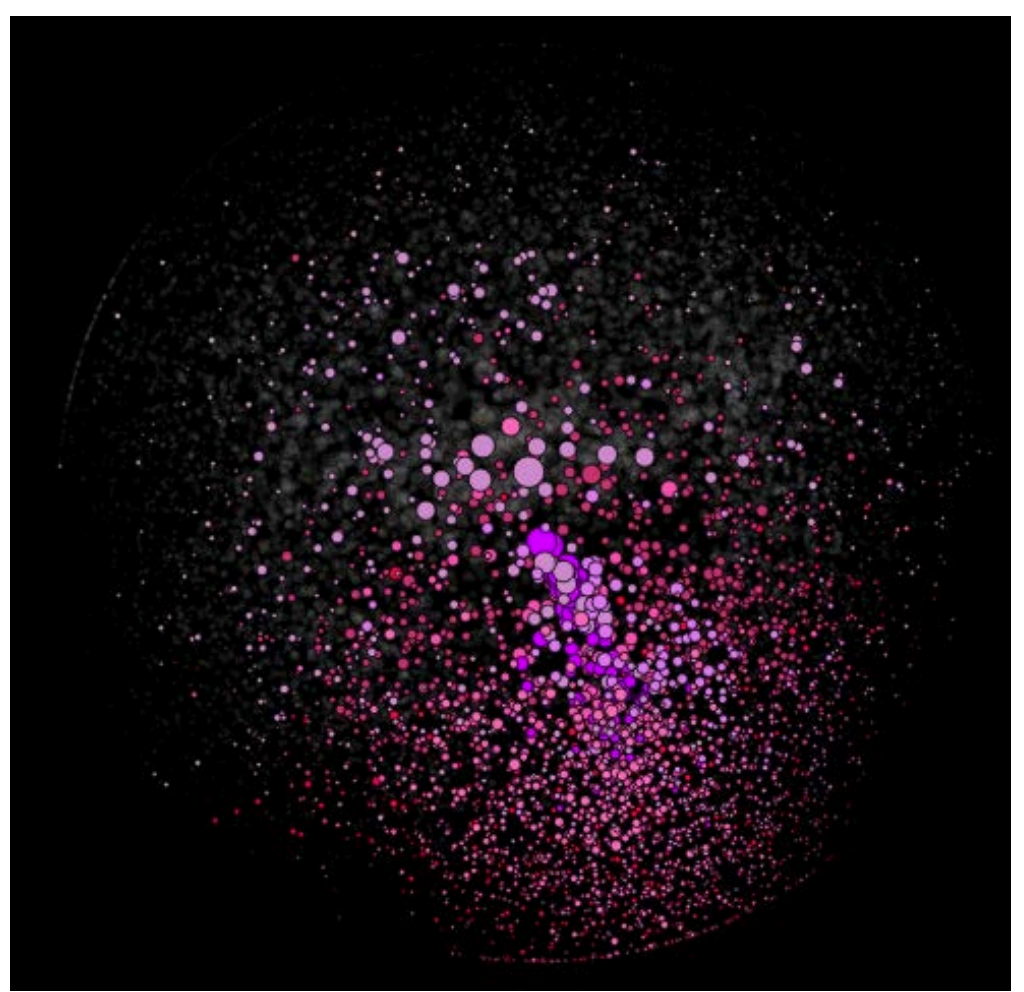

FIGURE 8. SEVEN GENERAL SOCIAL CONTENT CLUSTERS

There are seven General Social Content clusters on the map. The accounts in these clusters contain very little original content. Users tweet and retweet religious texts, proverbs, banal daily life observations, and general borrowed pieces of advice on a variety of issues. Some accounts have stronger content on one issue. They also comment on social media content that has often gone viral at the regional and global levels. Some accounts also have social media marketing content. Many of the accounts use Arabic tweeting automation services to post religious texts. Because most of the content in these clusters is borrowed, the same content appears across the entire network. The clusters are not conversational. 


\section{OTHER CLUSTERS}

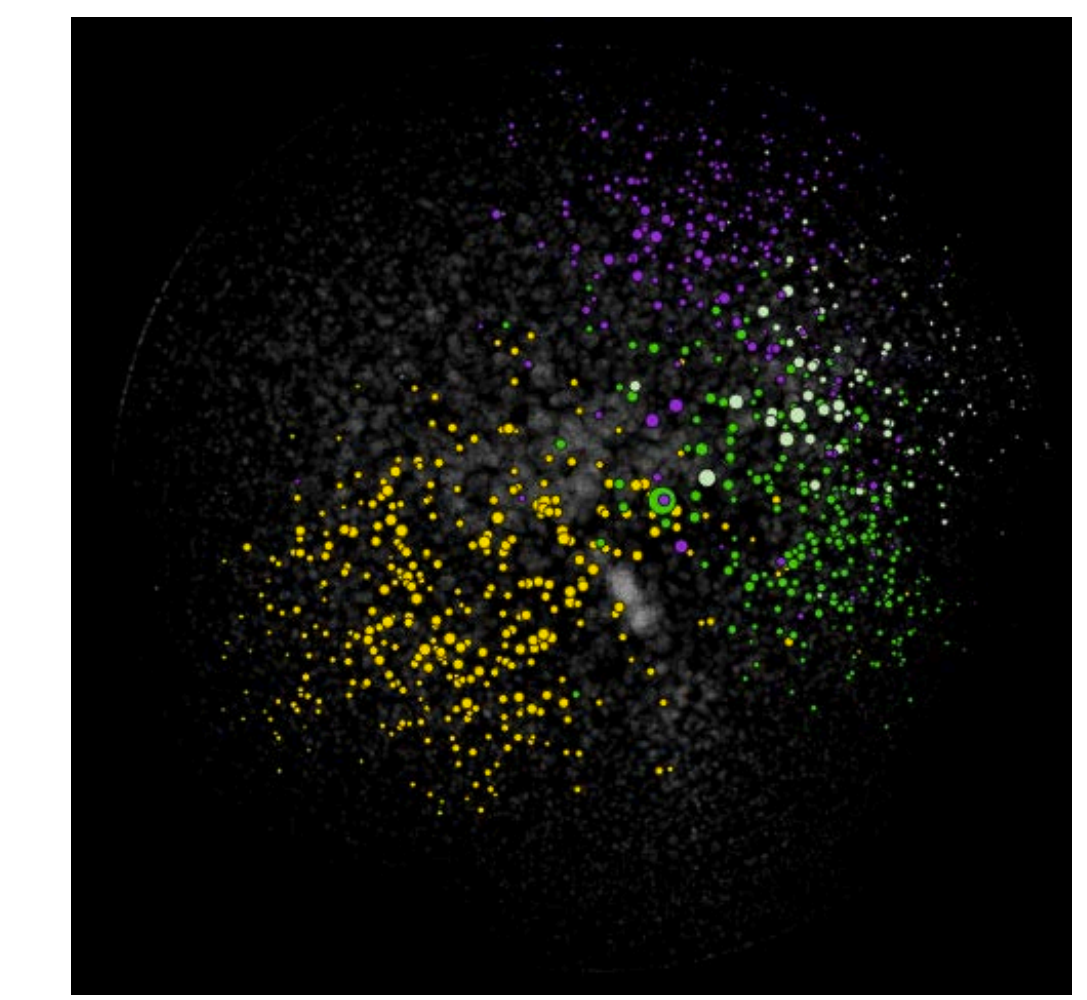

FIGURE 9. ENTERTAINMENT \& PERSONAL CLUSTERS

(SHOWBIZ 1 \& 2 IN GREEN AND LIGHT GREEN; COOKING, FASHION, AND HEALTH IN YELLOW; PERSONAL DIARIES IN PURPLE)

Two showbiz clusters emerge on the map (Regional Showbiz $1 \& 2$ ); each is populated by singers, actors, TV personalities, celebrities, and journalists from Saudi Arabia and the Arab world. Accounts of Saudi-owned TV channels such as the MBC group appear in this cluster. Many of the accounts have a high number of followers, with many over a million. Most of the accounts tweet news about entertainment productions and performances, and occasionally comment on major political news stories.

The Cooking, Fashion \& Health cluster is populated by users sharing food recipes, fashion design tips, and health advice. The Personal Diaries cluster is a community of users tweeting personal diary-type reflections and reacting to social, entertainment, and sports events. Users in this cluster supplement their tweeting activities with the use of religious messages using pre-selected content automated tweeting services. 


\section{REGIONAL CLUSTERS}

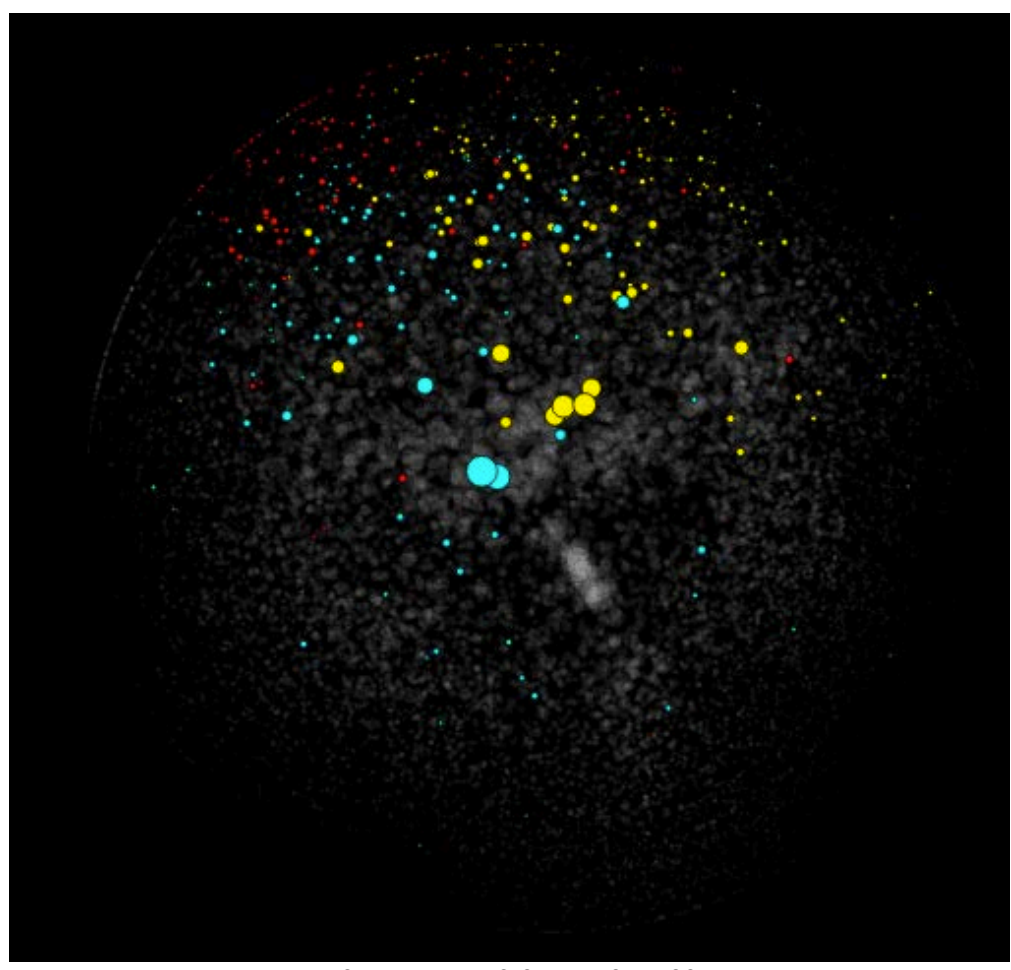

FIGURE 10. REGIONAL POLITICS

(KUWAITI POLITICS IN LIGHT BLUE; EGYPTIAN POLITICS IN RED; REGIONAL \& INTERNATIONAL POLITICIANS \& MEDIA IN YELLOW)

The Kuwaiti Politics cluster is comprised of Kuwaiti media, politicians, and religious figures discussing and commenting on local and regional political issues and current affairs. The users often discuss major Saudi political issues. Saudi users follow accounts in this cluster.

The Egyptian Politics cluster contains Egyptian politicians, journalists, and activists discussing both local and regional political issues, including some major Saudi political affairs such as the Kingdom's support for Egyptian President Abdel Fattah el-Sisi and the Kingdom's position on Egypt's Muslim Brotherhood. Many Saudi users follow accounts in this cluster.

The Regional \& International Politicians \& Media cluster contains accounts of politicians and media outlets from the region and Western countries. The cluster is not conversational. 


\section{MIXED CLUSTER}

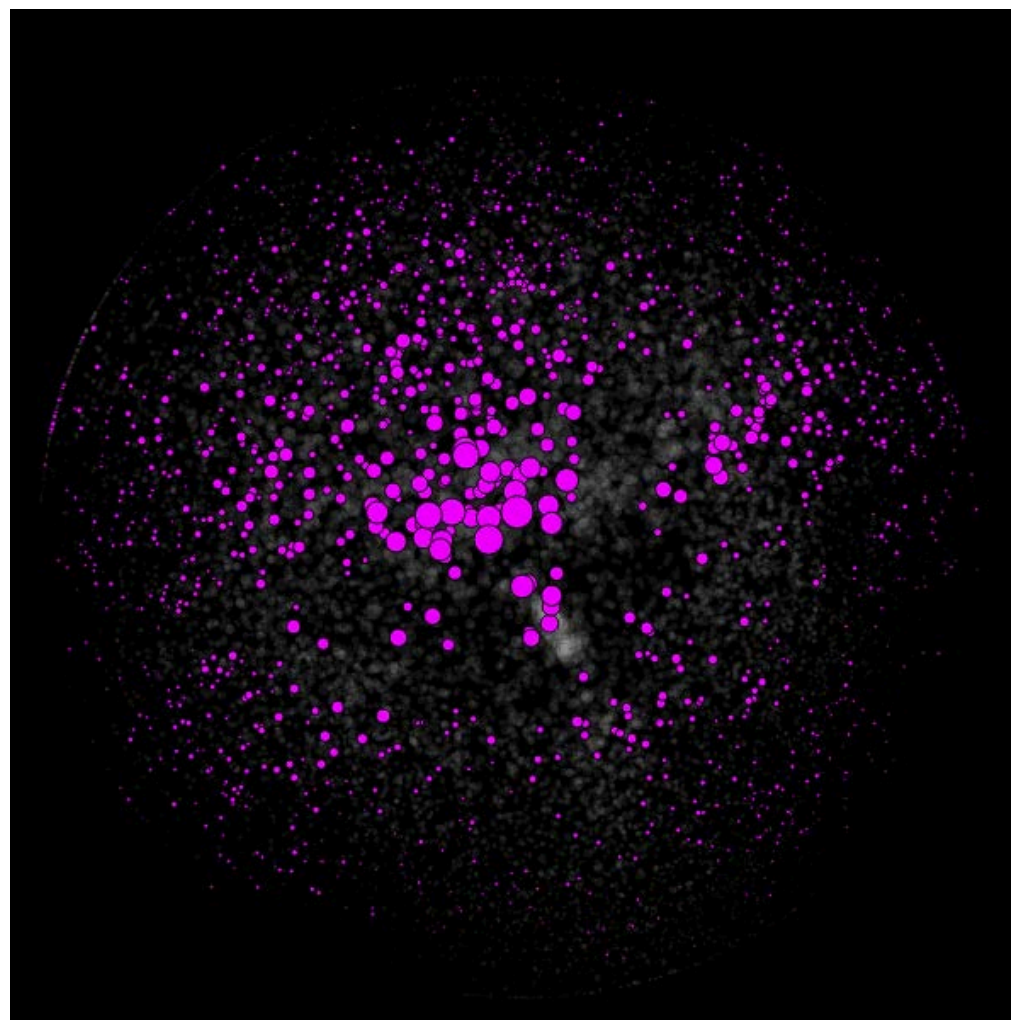

FIGURE 11. MIXED CLUSTER

This cluster contains Twitter accounts of diverse individual and institutional users focused on a range of topics including religion, sports, politics, entertainment, media, and social media marketing. There is no single thematic link to the accounts in this cluster.

\section{COMMUNITIES AND DISCOURSE IN THE SAUDI TWITTERSPHERE}

Mapping social media offers a unique perspective on Saudi social, religious, and political ordering. Twitter in Saudi Arabia is not restricted by technical filtering, but it is encumbered by social and political pressures, with risks for those who push against power and norms. It is, however, a platform for public discourse that offers unprecedented opportunities to broach and debate topics that were impossible just several years ago. The topics that appear prominently on Saudi Twitter, and those that do not, offer many insights into the social, cultural, and political fabric of the Kingdom-arguably more revealing than other perspectives.

Review of the top 100 accounts with the greatest number of followers from within the network highlights the relative prominence and range of interests found on Saudi Twitter (Table 4). ${ }^{\mathrm{E}}$ The number of followers offers a useful estimate of the relative prominence or influence of users in this network. ${ }^{\mathrm{F}}$

\footnotetext{
E Researchers manually reviewed the 100 accounts with the greatest number of followers (based on in degree) from within the network under study and placed them into the categories listed in the table.

F The social meaning of a follow relationship is indeterminate. For some it may signal endorsement or support of the views of the followee. In other cases it might be motivated by an interest in keep tabs on those with opposing social and
} 


\begin{tabular}{l|l|l|}
\hline CATEGORY & TOTAL NUMBER OF ACCOUNTS \\
\hline Religion & 30 \\
\hline General Interest & 19 \\
\hline Sports & 11 \\
\hline Politicians & 6 \\
\hline KSA Journalists & 5 \\
\hline Saudi Civil Society Actors & 5 \\
\hline Saudi Media & 5 \\
\hline Quote Retweeters & 5 \\
\hline Pan-Arab Media & 4 \\
\hline Arts \& Entertainment & 4 \\
\hline Arab Journalists & 2 \\
\hline Company & 2 \\
\hline Civil Society Organizations & 1 \\
\hline
\end{tabular}

Among the different categories, religious figures are by far the most followed in the map, comprising 30 of the top 100 accounts. This underlines that religion is a center of gravity and a contentious issue, as evidenced by the disparity of the discussants' interpretation of religious views. Sports figures such as journalists, officials, and fans occupy 11 of the top 100 spots, which is not a surprise given that 8 sports clusters appear on the map. Civil society voices are fewer (5), and there is only one civil society organization among the top 100 accounts. This is probably a reflection of the state restrictions on formal civil society organizing and action. Six politicians are among the top accounts, including the now-suspended account of the then Crown Prince, now incumbent King Salman bin Abdulaziz Al Saud, who started a new Twitter account after he became king. ${ }^{G}$ Two politicians from outside the Kingdom are among the six most followed: Muhammad Morsi, former president of Egypt who was ousted by the army; and Mohammed bin Rashid Al Maktoum, Vice President and Prime Minister of the United Arab Emirates and Emir of Dubai. Accounts associated with media combine to fill 16 of the top 100, including local media (5), Saudi journalists (5), panArab media outlets (4), and Arab journalists (2). No accounts of Western or international media appear among the most followed accounts. Accounts with general interest content such as religious sayings, proverbs, self-help tips, and social media marketing occupy a significant position on the map (19), which is probably due to the fact that their content is general in nature and can have universal appeal.

Many of the most followed figures in the different categories are TV personalities, which could have contributed to the size of their online audience. For example, many of the top followed religious figures (e.g., Mohamad al-Arefe and Salman Alodah) are frequent guests on TV channels. The psychologist Tarek Alhabeeb is also a TV personality. Similarly, the sports figures (e.g, B attal Algoos and Waleed Alfarraj) are TV journalists. Most of the Saudi and pan-Arab journalists among the most followed users in the network happen to be broadcast journalists. Examples include Abdullah

political views. There is no consensus on a definition of prominence or influence in sodal media, and we offer this metric as a rough proxy rather than a definitive measure of prominence or influence.

G It is likely that followers have switched to the new account. The map was generated before he became king. 
Almodifer (anchor at Rotana TV), Turki Aldakhil (TV anchor at Al-Arabiya TV), Faisal al-Qassem (host of the live debate show The Opposite Direction on Al Jazeera TV Arabic), and Ola Alfares (a presenter on MBC TV).

\section{USER LOCATION}

Drawing on the longitude and latitude coordinates included in the metadata for many of the users along with the location information provided by the users, we are able to infer the location of users across the different clusters. ${ }^{\mathrm{H}}$ For approximately $30 \%$ of the users, we are unable to ascertain their location. A number of accounts use metaphors such as "Islam" or a religious text as location, while others report broad locations such as the Arab world or Islamic world. For others, there is no information on location.

Overall, approximately two thirds of users are located inside Saudi Arabia (Figure 12; for detailed data, see Appendix A). Another 30\% of users are in one of the counties within the region (defined as countries in the Middle East and North Africa), and a small proportion (6\%) are from various countries worldwide.

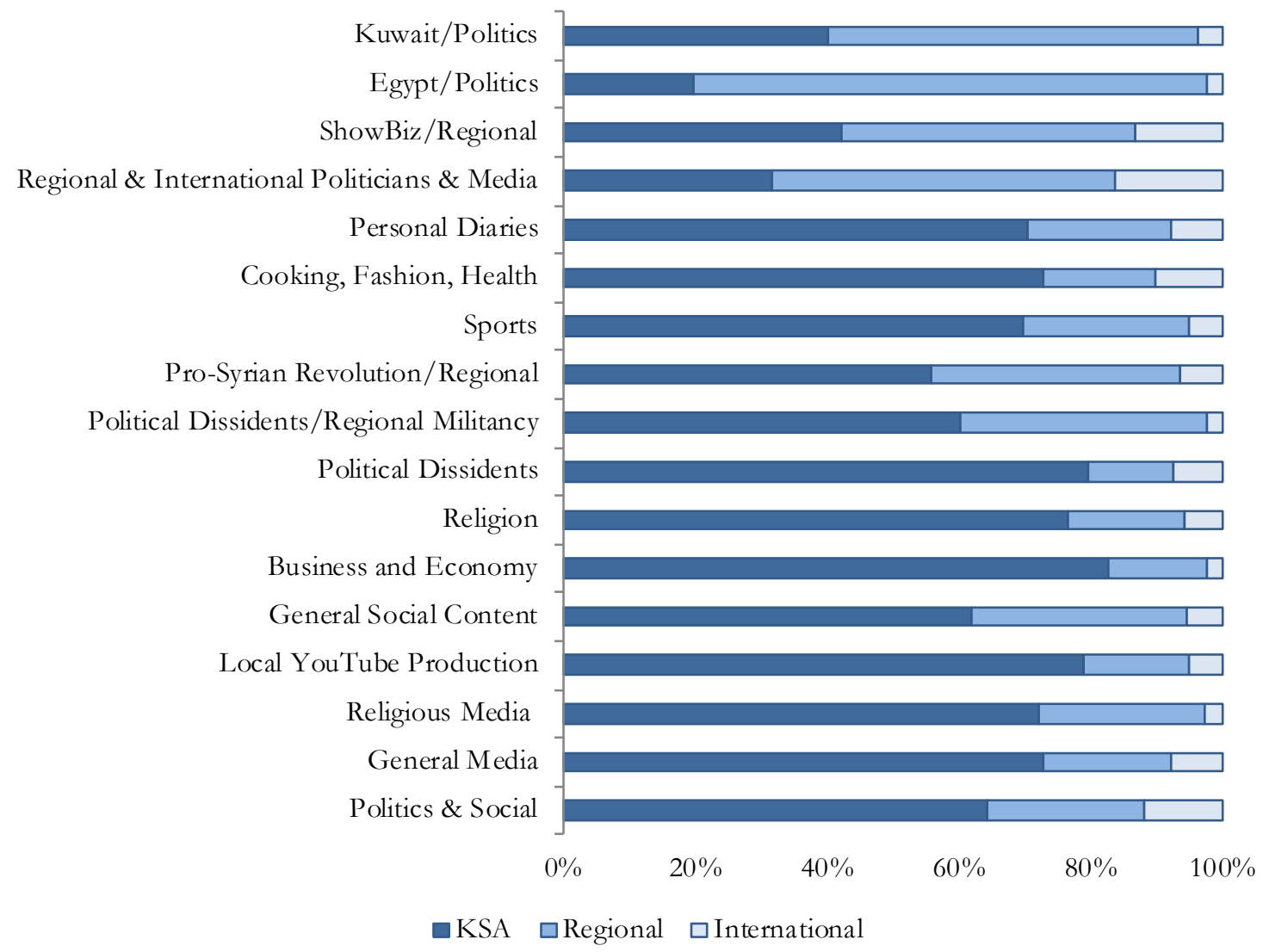

FIGURE 12. LOCATION OF ACCOUNTS BY CLUSTER

$\mathrm{H}$ As described in methods section, the network is comprised of accounts most highly connected to the central core of Saudi discourse on Twitter. This indudes accounts of Saudis living abroad and other users with strong links to the network. 
There is noticeable variation in the location of users across the different Saudi clusters. For example, users populating the two political dissident clusters are mainly located inside Saudi Arabia, but the cluster that also focuses on regional militants includes a larger proportion of users from the broader region.

The clusters with the highest percentage of users with local location are the business and economy cluster, followed by the political dissidence cluster. The fact that a high percentage of political dissidents reside inside the Kingdom and that many websites referenced by these users are blocked there suggest that the users use circumvention tools to bypass the filtering regime.

The general media and religious media clusters have almost the same percentage of users in the Kingdom, but there are more users from the region in the religious media cluster, while the general media cluster has more users from outside the region.

The data show an expected pattern; clusters with Saudi-focused discourse such as politics, media, religion, business, and sports have the highest percentages of users located inside the Kingdom, while clusters with regional users and content such as Egypt politics and regional showbiz have fewer users inside the Kingdom. The regional cluster populated by pro-Syrian revolution is an exception; users inside Saudi Arabia constitute a majority in this cluster.

\section{PROFILE PHOTOS}

We examined the use of profile pictures to explore whether this practice varies across the clusters and to try to explain the variation in user behavior. The use of profile pictures is one way in which Twitter users can shape their identity. Users who are seeking to build a public profile on Twitter may choose to identify themselves with their real name and include a photograph of themselves in their profile. Many others choose to tweet anonymously. We explore this one aspect of identity management on Saudi Twitter by categorizing the profile pictures used by the accounts in this network. This also allows us to explore whether user groups voicing strong political opinions reveal their faces or not, which clusters are more likely to show their real faces, and whether behavior among male and female users differs.

To tabulate user decisions on profile pictures, we retrieved user information of the 11700 accounts through the Twitter API and downloaded the profile pictures of the existing users. From the full set of 11,700 accounts, we manually reviewed 9,234 profile pictures. ${ }^{\mathrm{I}}$ We were unable to obtain profile pictures for the other accounts (approximately one fifth of the total accounts) either because the account has been since taken down or the user profile picture had been changed between the time that we gathered the links for the profile pictures from the Twitter API and scanned the pictures from the accounts.

We adopted a simple coding protocol to ascertain what proportion of the accounts included adult faces that are likely to be the actual face of the Twitter account holder. To arrive at these estimates,

\footnotetext{
I We first attempted to carry out this analysis in an automated fashion using Face ++ , an online service specializing in detecting features of human faces, induding gender, age, and race. The review of the results indicated that the automated approach missed important elements and variations so we settled on a manual review instead.
} 
we categorized the many alternatives used in the place of a profile picture into the following categories:

- Child: a photo or a sketch of a child or children.

- Borrowed: a photo or a sketch of a recognizable celebrity or public figure (e.g., politician, actor, singer, or footballer).

- National symbol: a national symbol such as the Saudi flag or a photo of a royal family member such as the current or a former king.

- Rabia sign: the sign used by the Muslim Brotherhood and their supporters to show solidarity with the group and president Morsi against what they consider a military coup in Egypt.

- Sports: graphics, sketches, or photos representing sports.

- Militant: a photo of a militant leader or a sign used by militants such as the Islamic State flag.

- Female graphics: a sketch, drawing, or photo of a female character or a sketch or drawing of an unknown woman.

- Religious content: religious text or a photo, sign, or sketch of a religious symbol such as the Quran or a mosque.

- Syrian revolution: graphics showing support for the Syrian revolution, most commonly the independence flag used widely by Syrian opposition.

- Egg: default Twitter icon.

- Graphics: graphical or symbolic image that does not fall within any of the above broad categories.

- Male face: a photo or sketch of a person likely to be the user.

- Female face: a photo or sketch of a person likely to be the user.

By removing the other alternatives, we are then left with photos or detailed sketches of human faces that are likely to be that of the user. Without conducting a deeper account-by-account inquiry, we cannot be certain that the remaining faces are those of the actual user. We are able to eliminate readily apparent efforts to present an image that would not in itself identify the user.

As summarized in Figure 13 (for detailed data, see Appendix A), we see that at least two thirds of users in the overall network include an image on their profile page that is not their own face. The proportion of users that include a photograph that appears to be their own face varies significantly from cluster to cluster. For example, users engaged in politics and social discussion use such photos most, and those interested in cooking, fashion and health least. Also, users in the general media cluster use the photos more than their peers in the religious media cluster. 


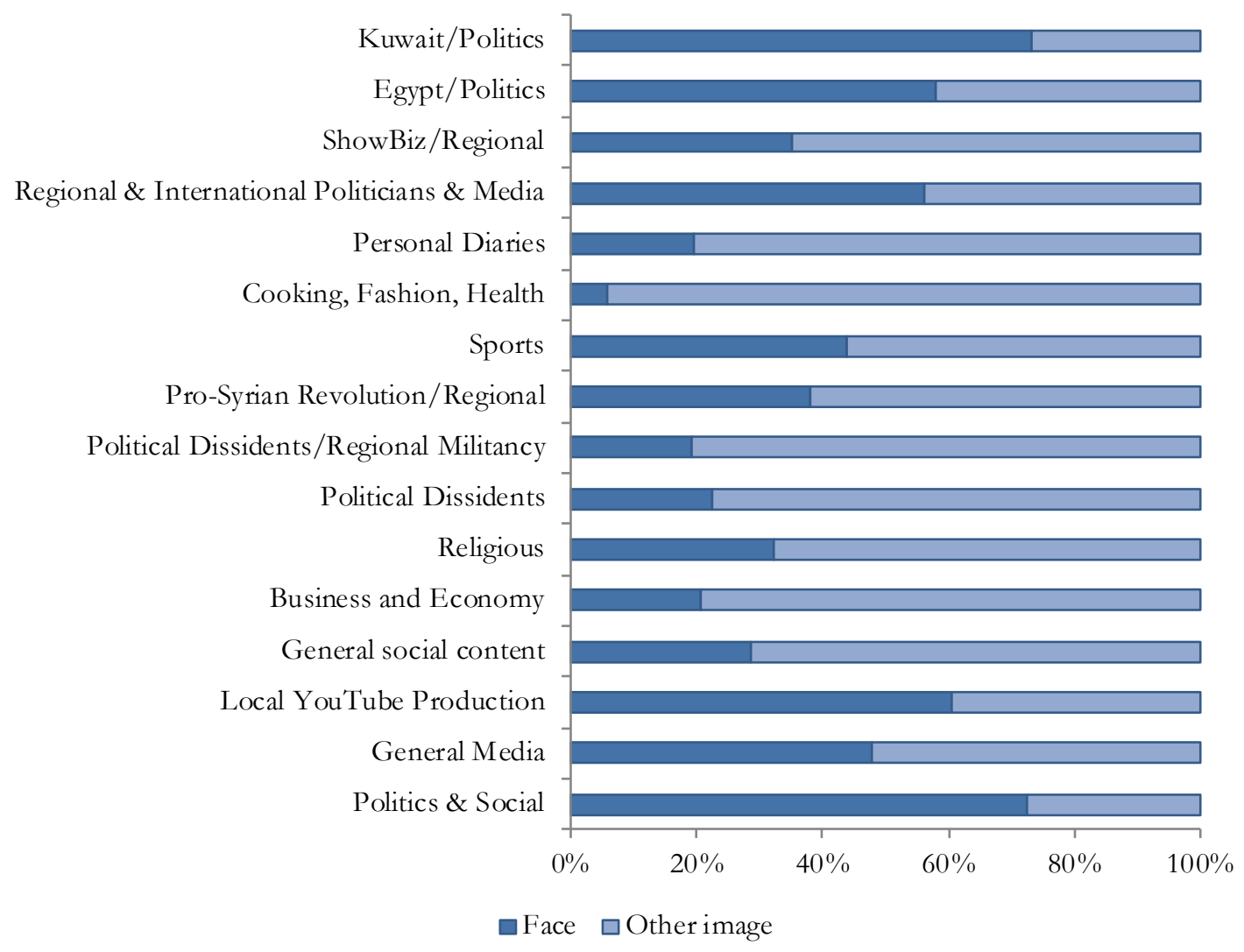

FIGURE 13. PROPORTION OF PROFILE PICTURES WITH ADULT FACES VERSUS OTHER IMAGES BY CLUSTER

The use of general graphics that do not fall within a distinct category is by far the most widespread (Table 5). The use of such graphics is most common among users who introduce themselves using a first name only or an obvious pseudonym. This combination is most visible in the two clusters that are populated mainly by political dissidents, which implies that these users want to remain anonymous. However, the use of such graphics is not always a mask; some users tweet with their real names yet use graphics instead of their photos. For example, some users in the Local YouTube Production cluster use artistic graphics. Some female users who introduce themselves with a female first name or female pseudonyms use female graphics such as a sketch of a female face, which indicates that such users want to remain anonymous yet assert their gender identity. General graphics are also widely used by users in the general social content clusters and those interested in cooking, fashion, health, as well as by those using automated posting tools to tweet religious content.

The use of what appears to be a real photo of the user is the second most common, and it is most commonly used by male users. This includes journalists, religious figures, and citizens commenting on local political and social affairs and sports activities. The proportion of accounts with a female face is far fewer; $31 \%$ of accounts include a male face compared to only $2 \%$ of accounts with female faces. We do not know how many of the accounts in the overall network are women and are therefore unable to estimate how much of the disparity is determined by behavior of female users and how much is the result of a larger percentage of male users in the network. It is reasonable to 
assume that both factors contribute. Saudi female users who include real photos are mostly public figures engaged in political and social life; these include journalists and civil society actors.

The use of a borrowed photo or a sketch of a celebrity or a public figure such as a popular politician, actor, singer, or football player is most common among users who post personal diaries, comment on political and social issues, and primarily post general social content. The use of a photo of a child or children is more prevalent among users in the religious media clusters. Sports graphics unsurprisingly occur most frequently in the sports cluster.

The use of religious text or graphics is comparatively limited and occurs most among religious preachers. Users posting general social content, supporters of the Syrian revolution, and users who have general interests also use religious text or graphics.

The use of national graphics such as the Kingdom's flag or a photo of royal family member, usually the King, is also limited, but witnessed a surge after Saudi Arabia led the military intervention in Yemen in March 2015. More users started using national symbols as their profile pictures, with some adding to the graphics or their profile summary the hashtag \# عاصفة الحزم (decisive storm), the name given to the military operation. National symbols are most often used by those interested in broad media, business, and economy, as well as sports fans. Use of national graphics is accompanied by national pride rhetoric and support for the military intervention in Yemen. 
Openness and Restraint

Structure, Discourse, and Contention in Saudi Twitter

\begin{tabular}{|c|c|c|c|c|c|c|c|c|c|c|c|c|c|}
\hline CLUSTER & $\begin{array}{l}\text { MALE } \\
\text { FACE }\end{array}$ & $\begin{array}{l}\text { FEMALE } \\
\text { FACE }\end{array}$ & $\begin{array}{l}\text { FEMALE } \\
\text { GRAPHICS }\end{array}$ & EGG & $\begin{array}{l}\text { BORROWED } \\
\text { IMAGE }\end{array}$ & CHILD & GRAPHICS & $\begin{array}{l}\text { NATIONAL } \\
\text { SYMBOL }\end{array}$ & RELIGIOUS & SPORTS & $\begin{array}{l}\text { RABIYA } \\
\text { SIGN }\end{array}$ & $\begin{array}{l}\text { SYRIAN } \\
\text { REVOLUTION }\end{array}$ & MILITANT \\
\hline Politics \& Social & 0.66 & 0.07 & 0.04 & 0.00 & 0.03 & 0.00 & 0.19 & 0.00 & 0.00 & 0.00 & 0.00 & 0.00 & 0.00 \\
\hline Business and Economy & 0.19 & 0.01 & 0.01 & 0.03 & 0.01 & 0.02 & 0.68 & 0.06 & 0.01 & 0.00 & 0.00 & 0.00 & 0.00 \\
\hline General Media & 0.43 & 0.04 & 0.02 & 0.00 & 0.01 & 0.01 & 0.43 & 0.03 & 0.01 & 0.01 & 0.00 & 0.00 & 0.00 \\
\hline Local YouTube Production & 0.52 & 0.08 & 0.03 & 0.00 & 0.00 & 0.00 & 0.35 & 0.01 & 0.01 & 0.00 & 0.00 & 0.00 & 0.00 \\
\hline Religious Media 1 & 0.32 & 0.01 & 0.02 & 0.01 & 0.00 & 0.03 & 0.59 & 0.01 & 0.01 & 0.00 & 0.00 & 0.00 & 0.00 \\
\hline Religious Media 2 & 0.10 & 0.03 & 0.05 & 0.01 & 0.00 & 0.05 & 0.74 & 0.00 & 0.02 & 0.00 & 0.00 & 0.00 & 0.00 \\
\hline Religious Academics & 0.35 & 0.01 & 0.01 & 0.02 & 0.00 & 0.00 & 0.56 & 0.01 & 0.04 & 0.00 & 0.01 & 0.00 & 0.00 \\
\hline Religious Preaching & 0.19 & 0.01 & 0.02 & 0.01 & 0.00 & 0.01 & 0.68 & 0.01 & 0.05 & 0.00 & 0.00 & 0.01 & 0.00 \\
\hline Religious Automated Tweeting & 0.03 & 0.01 & 0.00 & 0.01 & 0.00 & 0.03 & 0.85 & 0.01 & 0.05 & 0.00 & 0.00 & 0.00 & 0.00 \\
\hline Islam & 0.68 & 0.00 & 0.00 & 0.01 & 0.00 & 0.00 & 0.28 & 0.01 & 0.01 & 0.00 & 0.00 & 0.01 & 0.00 \\
\hline Personal Diaries & 0.16 & 0.04 & 0.13 & 0.01 & 0.07 & 0.04 & 0.54 & 0.02 & 0.00 & 0.00 & 0.00 & 0.00 & 0.00 \\
\hline Cooking, Fashion, Health & 0.04 & 0.02 & 0.08 & 0.00 & 0.00 & 0.01 & 0.84 & 0.00 & 0.01 & 0.00 & 0.00 & 0.00 & 0.00 \\
\hline Political Dissidents & 0.21 & 0.01 & 0.02 & 0.01 & 0.04 & 0.01 & 0.58 & 0.02 & 0.04 & 0.01 & 0.06 & 0.00 & 0.00 \\
\hline Dissidents \& Regional Militancy & 0.17 & 0.01 & 0.01 & 0.02 & 0.04 & 0.02 & 0.63 & 0.00 & 0.01 & 0.00 & 0.01 & 0.00 & 0.08 \\
\hline Pro-Syrian Revolution/Regional & 0.38 & 0.00 & 0.01 & 0.00 & 0.00 & 0.00 & 0.47 & 0.01 & 0.03 & 0.00 & 0.03 & 0.05 & 0.00 \\
\hline International Politicians \& Media & 0.42 & 0.13 & 0.01 & 0.01 & 0.02 & 0.00 & 0.41 & 0.00 & 0.00 & 0.00 & 0.00 & 0.00 & 0.00 \\
\hline ShowBiz/Regional 1 & 0.19 & 0.04 & 0.08 & 0.01 & 0.01 & 0.02 & 0.66 & 0.01 & 0.00 & 0.00 & 0.00 & 0.00 & 0.00 \\
\hline Showbiz/Regional 2 & 0.42 & 0.18 & 0.09 & 0.00 & 0.02 & 0.00 & 0.28 & 0.00 & 0.01 & 0.00 & 0.00 & 0.00 & 0.00 \\
\hline General Social Content 1 & 0.26 & 0.02 & 0.03 & 0.00 & 0.01 & 0.02 & 0.59 & 0.01 & 0.03 & 0.02 & 0.00 & 0.01 & 0.00 \\
\hline General Social Content 2 & 0.27 & 0.01 & 0.02 & 0.01 & 0.01 & 0.02 & 0.63 & 0.02 & 0.01 & 0.01 & 0.00 & 0.00 & 0.00 \\
\hline General Social Content 3 & 0.30 & 0.01 & 0.02 & 0.00 & 0.02 & 0.01 & 0.58 & 0.02 & 0.02 & 0.01 & 0.00 & 0.01 & 0.00 \\
\hline General Social Content 4 & 0.24 & 0.03 & 0.05 & 0.00 & 0.05 & 0.01 & 0.59 & 0.02 & 0.00 & 0.01 & 0.00 & 0.00 & 0.00 \\
\hline General Social Content 5 & 0.27 & 0.03 & 0.03 & 0.00 & 0.01 & 0.01 & 0.60 & 0.01 & 0.03 & 0.00 & 0.00 & 0.01 & 0.00 \\
\hline General Social Content 6 & 0.17 & 0.00 & 0.01 & 0.00 & 0.01 & 0.00 & 0.78 & 0.02 & 0.00 & 0.00 & 0.00 & 0.00 & 0.00 \\
\hline General Social Content 7 & 0.28 & 0.03 & 0.03 & 0.00 & 0.02 & 0.01 & 0.57 & 0.01 & 0.01 & 0.01 & 0.00 & 0.00 & 0.00 \\
\hline Sports 1 & 0.33 & 0.00 & 0.01 & 0.02 & 0.00 & 0.01 & 0.56 & 0.03 & 0.00 & 0.03 & 0.00 & 0.00 & 0.00 \\
\hline Sports 2 & 0.81 & 0.00 & 0.01 & 0.00 & 0.00 & 0.01 & 0.14 & 0.02 & 0.00 & 0.01 & 0.00 & 0.00 & 0.00 \\
\hline Sports/Al Ahli Football Club & 0.51 & 0.01 & 0.01 & 0.00 & 0.00 & 0.00 & 0.31 & 0.05 & 0.01 & 0.10 & 0.00 & 0.00 & 0.00 \\
\hline Sports/Al Hilal Football Club 1 & 0.47 & 0.00 & 0.02 & 0.00 & 0.00 & 0.01 & 0.38 & 0.07 & 0.01 & 0.04 & 0.00 & 0.00 & 0.00 \\
\hline Sports/Al Hilal Football Club 2 & 0.32 & 0.01 & 0.01 & 0.01 & 0.01 & 0.01 & 0.58 & 0.02 & 0.01 & 0.02 & 0.00 & 0.00 & 0.00 \\
\hline Sports/Al Hilal Football Club 3 & 0.61 & 0.00 & 0.00 & 0.00 & 0.00 & 0.00 & 0.30 & 0.00 & 0.01 & 0.08 & 0.00 & 0.00 & 0.00 \\
\hline Sports/Al Ittihad Football Club & 0.32 & 0.01 & 0.01 & 0.01 & 0.02 & 0.01 & 0.53 & 0.01 & 0.00 & 0.08 & 0.01 & 0.00 & 0.00 \\
\hline Sports/Al Nassr Football Club & 0.63 & 0.02 & 0.00 & 0.00 & 0.00 & 0.02 & 0.25 & 0.02 & 0.00 & 0.07 & 0.00 & 0.00 & 0.00 \\
\hline Kuwait/Politics & 0.67 & 0.06 & 0.01 & 0.00 & 0.01 & 0.00 & 0.24 & 0.00 & 0.00 & 0.00 & 0.01 & 0.00 & 0.00 \\
\hline Egypt/Politics & 0.55 & 0.03 & 0.01 & 0.00 & 0.01 & 0.01 & 0.30 & 0.00 & 0.01 & 0.00 & 0.07 & 0.00 & 0.00 \\
\hline Mixed & 0.21 & 0.01 & 0.02 & 0.01 & 0.03 & 0.00 & 0.66 & 0.01 & 0.02 & 0.02 & 0.00 & 0.00 & 0.00 \\
\hline All & 0.31 & 0.02 & 0.03 & 0.01 & 0.01 & 0.01 & 0.56 & 0.02 & 0.02 & 0.01 & 0.00 & 0.00 & 0.00 \\
\hline
\end{tabular}

TABLE 5. PROPORTION OF PROFILE PICTURES IN DIFFERENT CATEGORIES BY CLUSTER 
The Rabia sign that was widely used when we first reviewed the map is still seen, but is used most by political dissidents. A few non-Saudi users supporting the Syrian revolution and Egyptian users supportive of the Muslim Brotherhood also use the Rabia sign. Graphics showing support for the Syrian revolution against the Syrian government are used mostly by supporters of the Syrian revolution who populate a distinct cluster, as well as by a few users in Islam-focused clusters. The graphics are usually the Syrian independence flag, which has become a symbol of Syrian opposition to the government of Syrian President Bashar Al-Assad. Militant graphics, often the black and white flag used by the terrorist group Islamic State, are only used by militant accounts that populate the cluster Political Dissidents/Regional Militancy.

\section{KEY THEMES IN THE SAUDI TWITTERSPHERE}

Several key themes emerge from the analysis of the communities and discourse, which we summarize here:

\section{WHO OWNS ISLAM: DEBATES OVER LEGITIMATE HOLDERS OF THE FAITH}

Analysis of the collective discourse reveals an internal debate over legitimacy among those who vie for influence as interpreters of Islam. This issue permeates a large proportion of the conversations in the Saudi Twittersphere. Very few challenge the centrality of Islam to Saudi life. Islam is invoked by competing groups as the basis of their arguments on the various issues. In the Saudi Twittersphere, contention over true representation of the Islamic faith manifests across various fractures and disputes, including issues such as what constitutes an Islamic governance system and practices, what can be regarded as acceptable media content for Islam, and which intellectual thoughts can be considered to be within Islamic principles or are too liberal to be Islamic.

\section{DISSIDENT CLUSTERS ARE GROUNDED IN ISLAMIC IDEOLOGY}

The narrative used by the dissident community in their political dispute with the Saudi monarchy is based in Islamic rhetoric. Dissidents claim the monarchy is not a true representative of Islamic political and social principles and seek reform of the governance system with a grounding in what they consider true Islamic values. This fracture reflects an internal dispute over ownership of the concept of an Islamic state between the dissidents on one side and the monarchy and monarchyaligned religious establishment and supporters on the other. The dissidents often criticize the Saudi religious establishment for not being independent and for promoting the government interests. For example, Saudi dissident Saad Al-Faqih posts a comment critical of the Saudi Grand Mufti for calling on Saudi religious clerics to stay away from political affairs. ${ }^{6} \mathrm{He}$ also asserts a mandate to ensure that Islam, its principles, and Sharia law are the dominant forces in Saudi Arabia. ${ }^{63}$ The Saudi religious establishment, represented by The General Presidency of Scholarly Research and Ifta, ${ }^{64}$ often publishes research and edicts refuting claims of dissidents. However, this is usually done without naming or engaging in direct conversation with the dissidents. In one example, the establishment uses Islamic research to assert that obeying the rulers is an Islamic mandate. ${ }^{65}$ Clerics affiliated with the establishment issue strong edicts against revolutions that seek regime change. For example, Cleric Saleh al-Fawzan argues that "revolutions are fruitless. There is no good in a revolution even when it is against an oppressive ruler because it brings more damage such as bloodshed, disorder, and destabilization of security." "66 In essence, both sides, the dissidents and the loyalists, invoke Islamic principles as the basis of their arguments. This stands in contrast to other countries such as Egypt and Tunisia, where secular voices and arguments are prominent in the Twittersphere. 


\section{RIFT OVER MODERATE ISLAM}

At another level, the discourse in the non-dissident communities, which constitute the vast majority of the Twittersphere, reflects a rift between some conservative elements of the Saudi society and other segments that have less conservative approaches to political and social developments, as well as those who promote reform while trying to work from within the system. The conservatives and the not-so-conservatives are engaged in mutual public criticism, which at times can be fierce. For example, a Saudi self-described "enlightenment researcher and writer" tweets: "Thanks to the Saudi woman who suffers from the fatwas of ignorance and darkness which prevent her from driving, working and being independent from man, and the view that she is a disgrace." ${ }^{67}$ Other voices, however, consider advocates of moderate Islam as part of a suspicious agenda. One such voice, a female academic, writes: "May Allah protect our Kingdom and all Muslim countries from the Western plots that aim to divide our Muslim world and to tamper with our sanctities and promote so called 'moderate Islam.", 68

A lack of trust between some of the conservative voices and the reform-minded voices is evident in the narrative. One sample tweet says: "When a liberal talks about freedom of expression, he plots [to promote] atheism; when he talks about trust and religious tolerance, he plots for mixing [between the two sexes] and debauchery." "69 Also, some conservatives have strong objection to any calls to relax the current religious and social restrictions, and they viciously condemn any invitations to reconsider some of the current social norms for the benefit of the society. Such voices shut down any window for debating these issues. For example, a family counselor appearing on the private Saudi TV MBC channel said that Saudi young men and women should be allowed to meet in public places such as coffee shops to get to know each other as that will likely help them get married and reduce the rate of unmarried women. ${ }^{70}$ A cleric commented on the news, saying, "an MBC pimp calls for young men and women to meet in coffee shops to reduce the rate of spinsters.", 71 Moreover, the conservatives often refer to those who have alternative views on political and social issues with demeaning terms and promote these terms in hashtags. Examples include (translation from Arabic) \#mules_of_liberalism (referring to a person as a mule is offensive in the Arab culture) or \#liberal_diaspora (implying that the liberals in the Kingdom are outsiders to the society).

\section{CONTENTION OVER MEDIA CONTENT AND PROGRAMMING}

The ideological divide manifests itself in debates over TV programming. This is a recurrent topic in Saudi Twittersphere, with a particular focus on the programming of privately owned pan-Arab news based in Saudi Arabia and entertainment TV channels. Ideological perspectives on media content have a strong influence on the shape of the Twitter landscape as manifested in two communities for media professionals that surface in the network map. One cluster is centered on religious TV channels and religiously conservative media professionals. Another cluster is organized around those who have a broader and more liberal approach to media programming. The divide does not stop here. We found during the course of this study that segments of the Saudi Twittersphere population not only voice disapproval of certain TV channels, but also organize online campaigns against what they deem to be liberal, corrupting, and un-Islamic content. Users in the religion focus clusters direct their displeasure at MBC TV Channels ${ }^{72}$ in particular. For example, some users produced a YouTube video clip $^{73}$ urging Saudis to remove MBC group channels from their watch lists. Some tweets go as far as linking the MBC channels to foreign agendas; one made the dubious claim that $\mathrm{MBC}$ receives one billion dollars annually from the US Department of State, and that "explains why the MBC group spreads vice and fights Islam." "T4 This tweet was questioned and ridiculed by reply tweets which described it as a fabrication and the user as a liar. Other users object to the news 
programming and editorial policies of privately owned Saudi TV channels. They, for example, criticize these channels for not showing "sufficient sympathy" to Gazans and for criticizing Hamas' militant activities during the July-August 2014 Israeli military action on Hamas-controlled Gaza. The users led a campaign targeting the Saudi pan-Arab news TV channel Al Arabiya over this issue. For example, users celebrated reports that an Israeli soldier was captured by Hamas and commenting with a sarcastic Arabic hashtag: "Our condolences to Al Arabiya TV on the kidnapping of the Israeli soldier." 75 During the same period, another campaign targeted Saudi writers and intellectuals labeled by the campaign as "gang of shame" 76 and accused them of being complicit in the "Israeli aggression on Gaza" because they voiced their disapproval of the militant groups' activities.

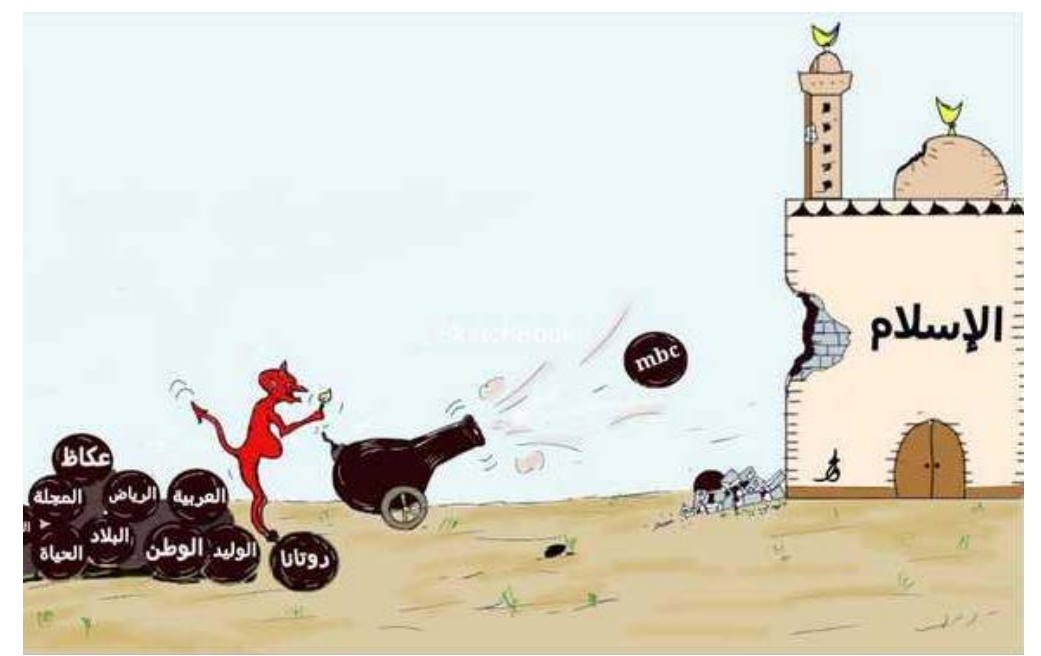

FIGURE 14. GRAPHIC POSTED IN A TWITTER CAMPAIGN BY RELIGIOUS CONSERVATIVES AGAINST SAUDI LIBERAL MEDIA. THIS ONE SUGGESTS THAT SAUDI TV CHANNELS SUCH AS MBC, ROTANA, AND AL ARABIYA, AS WELL AS SOME LOCAL NEWSPAPERS, ARE DESTROYING ISLAM AND ITS RELIGIOUS INSTITUTIONS. THE ARABIC WRITING ON THE MOSQUE IS "ISLAM." 77

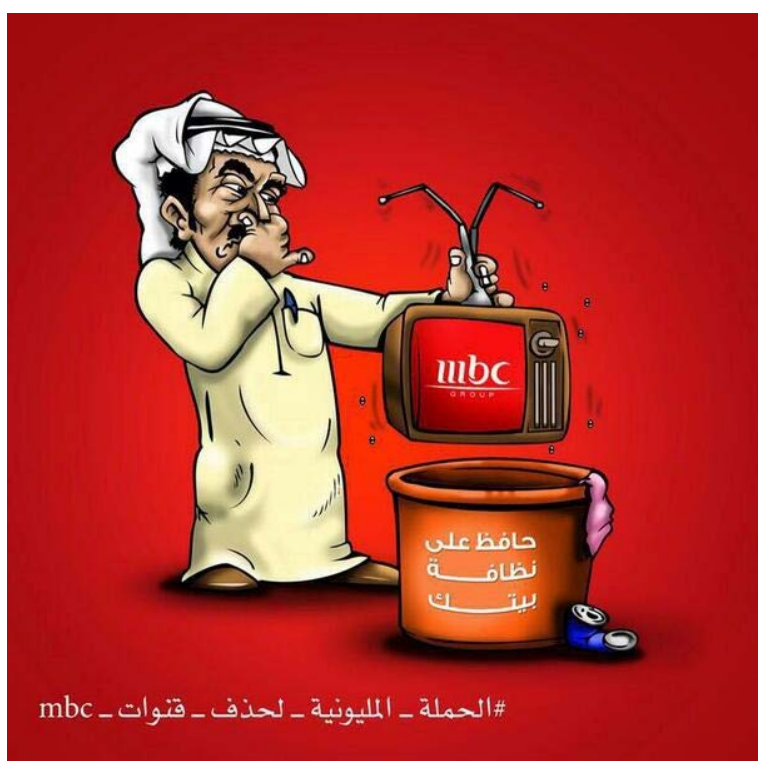

FIGURE 15. GRAPHIC USED AS PART OF THE TWITTER CAMPAIGN ORGANIZED BY SAUDI RELIGIOUS CONSERVATIVES TO REMOVE SAUDI LIBERAL TV CHANNELS FROM VIEWERS' WATCH LISTS. THE ARABIC WRITING ON THE BIN IS "KEEP THE ENVIRONMENT CLEAN." THE ARABIC HASHTAQ PRINTED ON THE GRAPHIC IS "THE ONE MILLION MEMBER CAMPAIGN TO REMOVE MBC GROUP CHANNELS [FROM WATCH LISTS]." 78 


\section{GOVERNMENT CLOUT: CITIZENS ALIGN THEIR PUBLIC SENTIMENTS WITH OFFICIAL POLICIES}

Many Saudi users appear to take into consideration official government policies as they express their political sentiments on Twitter. A notable example of this is the rapid decrease of support for the Muslim Brotherhood in Egypt following a Saudi government policy that supported the group's removal from power. We found during our initial review of the Twittersphere in July 2013 that many accounts supported the Muslim Brotherhood in Egypt and then Islamist president Mohammed Morsi against what they considered a military coup that ousted Morsi. Users showed support by displaying the Rabia sign J on their profiles and using Arabic hashtags such as الانقلاب_العسكري_بمصر ("Military Coup in Egypt"). The support stemmed from the view that the democratic process in Egypt should be given a chance, not necessarily because the users were Muslim Brotherhood affiliates. This support was seen across the entire map, and most visibly in the religion focus clusters. On July 4, 2013, just four days after the ousting of President Morsi, the King of Saudi Arabia Abdullah bin Abdulaziz Al Saud said in a letter sent to Egyptian interim president Adly Mansour that he strongly supported the armed forces represented by General Abdel Fattah al-Sissi. ${ }^{79}$ Users started a collective withdrawal of support for the Muslim Brotherhood after the Saudi King officially supported the removal of president Morsi. In March 2014, the Kingdom designated the Muslim Brotherhood, Islamic State, and Al-Nursa Front as terrorist organizations and criminalized "expressing sympathy" with any of these organizations. ${ }^{80}$ We revisited the map after this designation and found that users have almost entirely stopped using the Rabia sign, using hashtags sympathetic to Muslim Brotherhood, and referring to the removal of President Morsi as a military coup.

Relatedly, Saudi clusters exhibited support for Gazans by tweeting graphic images of Palestinian civilian casualties and featuring sympathetic hashtags during the Israeli war on Gaza in July-August 2014. However, the support and sympathy even among Islamists stopped short of explicitly supporting Hamas, apparently over concern that this sympathy can be criminalized, given that Hamas is linked to the Saudi-blacklisted Muslim Brotherhood.

We can infer from this collective behavior online that the Saudi government policies have chilling effects on citizens' decisions to express opinions on political issues publicly. This behavior can also suggest that not all sentiments are indeed expressed in the Twittersphere and that Saudis might be withdrawing opinions on other issues for the same reason.

\section{GENDER REPRESENTATION}

Women's voices did not emerge as a distinct cluster; rather, they are diffused across the Twittersphere. No obvious and distinguishable gender-based attitudes towards the many issues being debated in the Twittersphere emerged. For example, while there are publicly known Saudi women activists leading the campaign to allow women to drive (e.g., Saudi activist Manal Al-Sharif), there are counter-campaigns using hashtags such as "the nation's women against driving on [October] 26th" (\#بناد_26), and a few campaigns purporting to be run by women, such as Saudi Women Against Driving (https://twitter.com/Against_Driving). However, it is hard to verify if and how many of the accounts behind such campaigns are indeed run by women.

J The Rabia sign is a reference to the location in Cairo-Rabia Square-where a large sit-in took place in August 2013 to protest the removal of the Morsi-led government by the military. Thousands of people were killed or injured when the protests were dispersed by the Egyptian security forces. The Rabia sign is a symbol of solidarity with the Muslim Brotherhood and opposition to the government of President Abdel Fattah el-Sisi. 


\section{SHIA VOICES ON SAUDI TWITTERSPHERE}

Although Shia comprise a significant proportion of the population in Saudi Arabia (estimated to be between $10-15 \%$ of the population), ${ }^{81}$ no distinct Shia clusters appear on the map. This is in sharp contrast to Bahrain, where a similar mapping study found the Twitter landscape to be divided along sectarian lines and where a Saudi Shiite community populated a regional cluster ${ }^{82}$ The principal structures of the Bahraini map reflect Sunni and Shia religious affiliations. In Saudi Arabia, sectarian grievances do not play a prominent role in the discourse on Saudi Twittersphere. This might be attributed to Shia individuals and communities keeping a low profile, not identifying themselves based on religious affiliation, or not basing their follow decisions in the Saudi Twittersphere on sectarian grounds.

\section{PASSIVE ENGAGEMENT AND USE OF TWITTER AUTOMATION TOOLS}

A segment of the Saudi Twitter population appear to be heavy users of pre-selected Arabic content Twitter automation services that post mostly religious messages such as Qur'anic verses, prophetic sayings, and quotes from religious books and scholars. Most of these services are developed for religious reasons and are offered for public use for free. While some users in various clusters use these services to supplement their social engagement and Twitter activities, others seem to be solely using these services.

\section{CASE STUDIES}

The following case studies examine three issues that received widespread attention on Twitter at the national level.

\section{THE CASE OF RAEF BADAWI}

The public flogging of Raef Badawi in January 2015 was discussed intensively in the Saudi Twittersphere. Badawi is a Saudi citizen who was sentenced to 1,000 lashes and 10 years in prison for running an online liberal forum and for insulting Islam. ${ }^{83}$ Most of the discussion did not focus on the punishment itself, i.e., whether it was appropriate to flog a citizen over his online writings and political and religious views. Rather, most of the users used the event to advance their causes. For example, the political dissidents denounced the international media for focusing on Raef Badawi and not giving what they called violations against political opponents the same level of attention. One tweet states, "BBritish newspaper] The Independent says Saudi is brutal with the opposition. Why didn't you mention the brutality except with Raef Badawi? ${ }^{84}$ When news broke that the flogging was paused and that the king had ordered a review of the sentence ${ }^{85}$ some tweets in the dissident clusters suggested that the decision had come in the context of the Kingdom's subjection to the US. They tweeted a cartoon showing Uncle Sam telling a person (presumably representing Saudi Arabia), "You must cancel the flogging of Raef Badawi," and the person saying, while kissing Uncle Sam's shoes, "If you want, I will cancel all of the Islamic laws." ${ }_{86}$

Users in religion focused clusters tweeted the news about the flogging without questioning the appropriateness of the punishment, but some used the incident to lambast and defame their ideological opponents. One religious preacher, for example, writes, "The toilet known as 'the liberal forum' founded by Raef Badawi with the help of some heretics and where many mules of liberalism used to gather was full of heresy, atheism, and debauchment." ${ }^{87}$ 


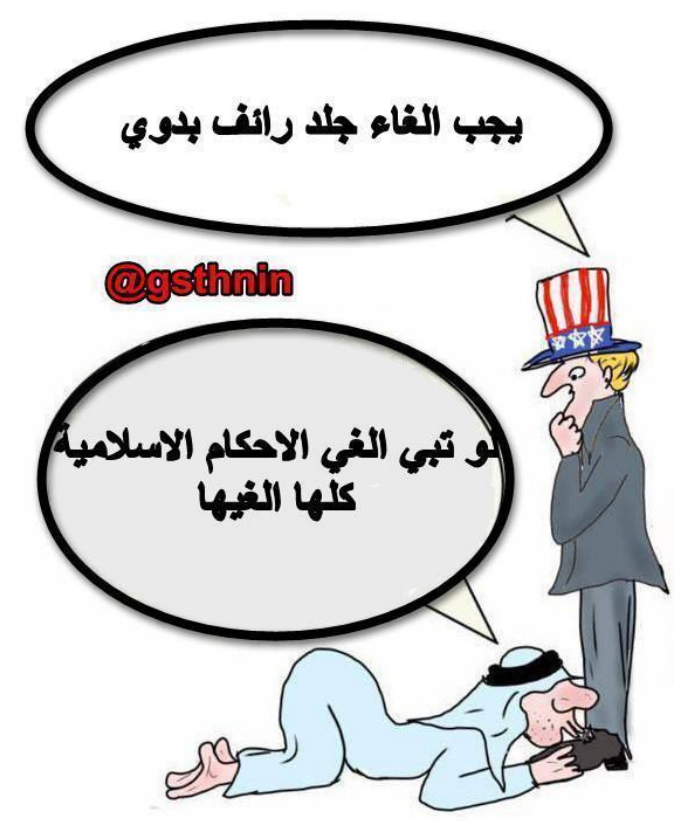

FIGURE 16. UNCLE SAM: "YOU MUST CANCEL THE FLOGGING OF RAEF BADAWI." PERSON: "IF YOU WANT, I WILL CANCEL ALL ISLAMIC LAWS."

\section{CHARLIE HEBDO}

The attack on Charlie Hebdo was a central focus of debate in the Twittersphere, with many using the generic hashtag \#charliehebdo and its Arabic equivalent (شارلي_ايبدو). The sentiments expressed were diverse and reflected the rift in religious and political outlooks. Many discussants used the occasion to air broader political grievances rather than addressing the core issue.

Many writers and journalists condemned the killing of the Charlie Hebdo journalists and cartoonists. One said, "Killing journalists is a condemned crime. Words should be challenged by words, not bullets." 88 On the other hand, tweets in the political dissidence clusters did not condemn the terrorist attack on the satirical magazine, but rather shifted the focus to criticizing Saudis who expressed sympathy with the cartoonists and those who participated in the international solidarity march in Paris in January 2015. They argued that such sympathetic messages and participating in the march undermine respect for prophet Mohammed especially because, the tweets said, some of the participants in the march carried satirical drawings of the prophet. ${ }^{89}$ Some tweets were particularly critical of the Saudi government's participation in the march and used the event to highlight what they considered inconsistency of the Saudi-aligned religious establishment on the issue of political demonstrations. A tweet posted an old statement issued by the Grand Mufti of Saudi Arabia in which he allegedly objected to the concept of organizing public protests, saying organizing marches to show support to Gazans during the Israeli war on Gaza is useless. The tweet commented on the statement saying "but participating in the march in France is ok, ok, ok," implying that the Mufti did not issue a statement objecting to the Saudi government participation in the march in Paris, yet had reservations on pro-Gaza marches.

Tweets in various clusters invoked what they called historical atrocities in France-occupied Algeria. They showed graphic photos of what they described as citizens killed in Algeria during the French 
colonial period. One tweet commented on the photos saying "One million were killed in Algeria, yet France did not apologize. Twelve were killed in France and all Arabs apologized." "91 Some tweets criticized the Arab states' participation in the international march, but did not mention Saudi Arabia's participation. One tweet included a photo of what it described as the Jordanian king shedding tears during the march with the comment, "See people shedding tears for those who ridicule prophet Mohammed, yet they did not shed any tears for the children and women of Syria who are being killed and displaced." 92

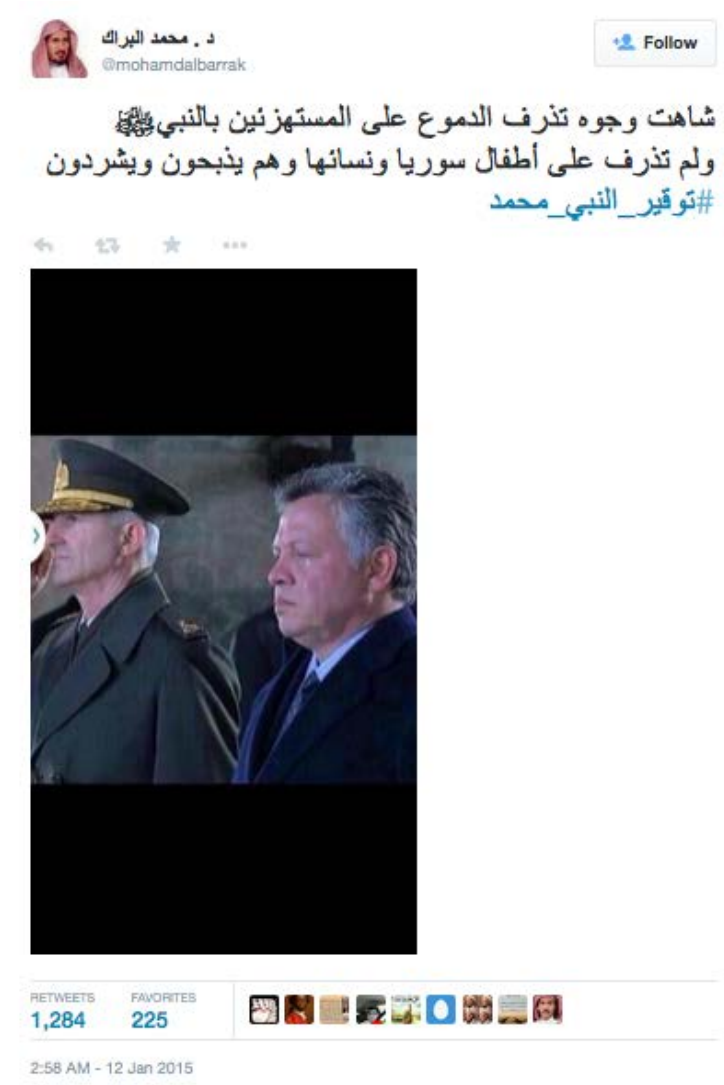

FIGURE 17. "SEE PEOPLE SHEDDING TEARS FOR THOSE WHO RIDICULE PROPHET MOHAMMED, YET THEY DID NOT SHED ANY TEARS FOR THE CHILDREN AND WOMEN OF SYRIA WHO ARE BEING KILLED AND DISPLACED."

\section{SAUDI-LED MILITARY AIRSTRIKES IN YEMEN}

On March 25, 2015 a Saudi-led coalition of Arab states launched an airstrike campaign on Shia Houthi rebels' positions in Yemen to defend and protect the internationally recognized government of the president of Yemen, Abdrabbuh Mansour Hadi. Hadi took refuge in the city of Aden after he fled the capital city of Sana'a, where he had been under house arrest since the Houthis took full control of the capital in January 2015. ${ }^{93}$ The aim of the military campaign, according to the Saudi Ambassador in Washington, was "to prevent Yemen from falling into the hands of the Houthis" and to restore the deposed government. ${ }^{94}$

After the launch of the military campaign, Saudi users took to Twitter to comment on the military

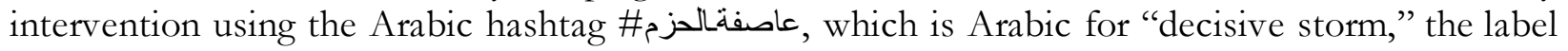
Saudi authorities gave to the military operation. About 1.4 million posts were tweeted under the hashtag in less than 8 hours, and the hashtag became the second highest trending topic globally. ${ }^{95}$ 
Commentary on the Saudi-led military campaign in Yemen is marked by two features. First, the comments on the Saudi military offensive appear in almost all of the clusters, including the nonpolitical ones such as sports and entertainment. Second, generally speaking, users express support to the airstrikes or show no objection to the Saudi military engagement in Yemen when discussing the war. Many u sers express support to the military intervention as a necessary measure to prevent what they call the Iranian and Iran-backed Shiite threat to Yemen and Saudi Arabia.

The religion-themed clusters stress that the war in Yemen has a sectarian dimension, and many accounts use religiously demeaning terms such as "Rafida" and "Safadeens" to refer to the Houthi rebels and Iran. ${ }^{97}$ Users in these clusters express the strongest support for the Saudi military engagement, and discussion of the war is comparatively more frequent. Users portray the conflict as a religious war between Sunnis and Shiites. ${ }^{98}$ One tweet, for example, says the "decisive storm which is crushing the Houthis and their supporters is a great Jihad ... congratulations to the Sunni community." "In this context, many users underscore that the Saudi army is an "army of faithful" in a position for victory. They share photos showing Saudi military men performing group prayers in uniform on aircraft carriers, in the desert, and beside fighter jets.

Many users outside the religion-focused clusters have a non-religious view on the conflict. One journalist for example emphasizes that the conflict is not sectarian. ${ }^{100}$

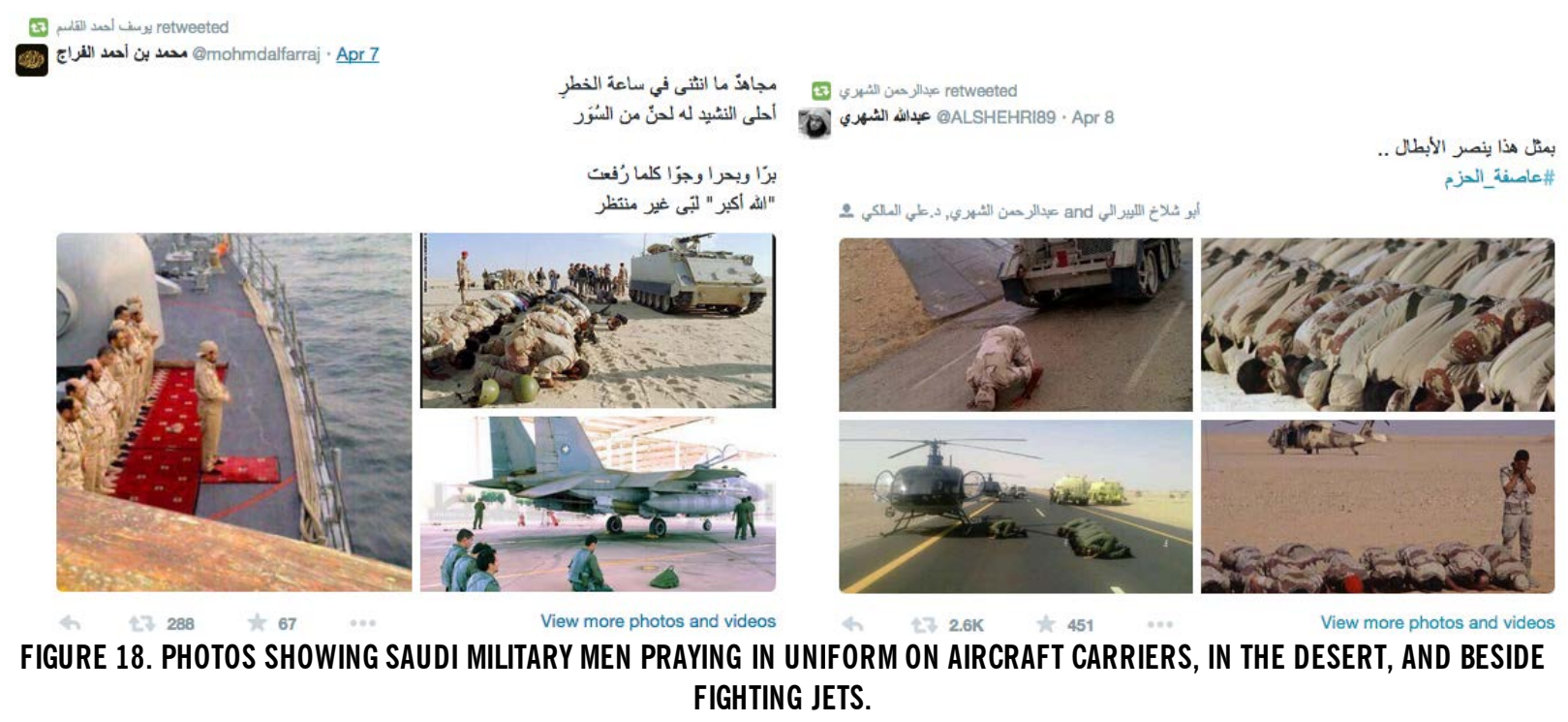

The overall narrative in the dissident clusters does not express any objection to the military war against the Houthi rebels, but members of the clusters use the occasion to discuss what they perceive as vulnerabilities within the Kingdom that weaken its military strengths. Tweets mention what they consider "Islamic" shortcomings within the Saudi governance system that debilitate its capacity to win a war. A tweet says Saudi Arabia uses an interest-based banking system, ${ }^{101}$ a system they consider un-Islamic. Another tweet says the state and the people of Saudi Arabia are not prepared to engage in a war because of internal challenges that have not been addressed for years, including poverty, housing, political prisoners, and unemployment. ${ }^{102}$ Other tweets discuss what they call Saudi Arabia's inconsistency in dealing with Iran-backed groups. One, for example, says Saudi Arabia supports the Iran-backed Iraqi government that "oppresses" Sunnis in Iraq, yet fights Iran- 
backed Houthi rebels who fight Sunnis in Yemen. ${ }^{103}$ An account using the Arabic sarcastic pseudonym "My Royal Highness" posts in a sarcastic tone, "Our rulers may Allah protect them side with the legitimate president in Yemen, yet support a military coup in Egypt. They fight Iran in Yemen and collaborate with it in Iraq. Hypocrisy is always inconsistent." ${ }^{104}$

\section{DISCUSSION AND CONCLUSION}

Twitter serves multiple functions in Saudi Arabia. It serves as a venue for Saudi citizens to express their opinions and sentiments and to engage in conversations on political and social issues. Citizens use the platform to vent their dissatisfaction with government public services and to highlight issues of corruption and government inefficiency. Because the Kingdom applies restrictions on civil society and civic action, Twitter helps citizens raise the visibility of grievances such as economic hardship, unemployment, and women's rights, and to demand government action on these issues.

The study of Twitter provides us with a window into contentious political, religious, and social issues debated by local actors. These debates can escalate into offensive information campaigns between rival groups and viewpoints. Many of the debates on Twitter are centered on the true representation of Islam, reflecting internal intellectual and political fractures. A common manifestation is religious conservatives and reformists engaging in fierce criticism of one another and information campaigns over what constitutes moderate Islam and acceptable media content.

Because Twitter exists outside of Saudi jurisdiction, and given the apparent inability of Saudi censors to block individual Twitter account pages and censor objectionable tweet streams that are accessible via mobile and desktop applications, political dissidents exploit this openness to disseminate oppositional messages despite the risks of participating in social media. Equal access to the medium has provided a venue for voices and opinions that would otherwise have been blocked, revealing not only the deep internal rift between conservatives and reformers but also the divide between loyalists and dissidents. Although they rarely engage in direct conversation, opponents and loyalists are entrenched in an intense dispute over issues, for example defining what qualifies as an Islamic governance system and evaluating the merits of different political and social policies. Saudi authorities are left with the challenge of suppressing or countering unwanted content through nontechnical means.

Despite the vibrant conversations and communities that have emerged on Saudi Twitter, there is evidence that legal restrictions, cultural norms, and political pressure influence and constrain the discourse. One example we are able to document is users' collective withdrawal of political sentiments that described the Egyptian army's removal of President Morsi from office in 2013 as a military coup. The users apparently elected to remove content that might clash with government support of the Egyptian army. The Saudi Twittersphere is thus best viewed as a digital landscape of opinions that are subject to self-censorship, particularly when they conflict with government positions.

The rise of Twitter in Saudi Arabia as a popular platform for open communication that is currently beyond the reach of technical filtering mechanisms has broadened the scope of public discourse while widening participation of citizens in debate and information sharing. And for those Saudis on Twitter who conceal their identities or refrain from expressing controversial attitudes, it also serves as a prime example of the abiding power of non-technical controls in limiting freedom of expression. 
It remains to be seen how the proposed new information controls might impact the communities and discourse on Saudi Twitter. Should the recommendations of the March 2015 conference be implemented, we should expect an increase in the use of surveillance and monitoring as techniques to control Twitter activity, and a coordinated regional effort to locate and prosecute users that cross the boundaries of acceptable political and social speech. We may also see popular accounts of celebrities enrolled in information campaigns. Future research will be needed to examine the influence of such measures on Twitter in Saudi Arabia. 


\section{APPENDIX A: ADDITIONAL DATA}

\begin{tabular}{|l|r|r|r|}
\hline CLUSTERS & KSA & REGIONAL & INTERNATIONAL \\
\hline Politics \& Social & 0.64 & 0.24 & 0.12 \\
\hline General Media & 0.73 & 0.19 & 0.08 \\
\hline Religious Media & 0.72 & 0.25 & 0.03 \\
\hline Local YouTube Production & 0.79 & 0.16 & 0.05 \\
\hline General social content & 0.62 & 0.32 & 0.05 \\
\hline Business and Economy & 0.83 & 0.15 & 0.02 \\
\hline Religion & 0.77 & 0.18 & 0.06 \\
\hline Political Dissidents & 0.80 & 0.13 & 0.08 \\
\hline Political Dissidents/Regional Militancy & 0.60 & 0.38 & 0.02 \\
\hline Regional Pro-Syrian Revolution & 0.56 & 0.38 & 0.06 \\
\hline Sports & 0.70 & 0.25 & 0.05 \\
\hline Cooking, Fashion, Health & 0.73 & 0.17 & 0.10 \\
\hline Personal Diaries & 0.70 & 0.22 & 0.08 \\
\hline Regional \& International Politicians \& Media & 0.32 & 0.52 & 0.16 \\
\hline Regional ShowBiz & 0.42 & 0.45 & 0.13 \\
\hline Egypt/Politics & 0.20 & 0.78 & 0.02 \\
\hline Kuwait/Politics & 0.40 & 0.56 & 0.04 \\
\hline All & 0.65 & 0.29 & 0.06 \\
\hline
\end{tabular}

TABLE A1. PROPORTION OF LOCATION OF ACCOUNTS BY CLUSTER

\begin{tabular}{|l|r|r|}
\hline CLUSTERS & ADULT FACE & OTHER IMAGE \\
\hline Politics \& Social & 0.73 & 0.27 \\
\hline General Media & 0.48 & 0.52 \\
\hline Religious Media & 0.25 & 0.75 \\
\hline Local YouTube Production & 0.61 & 0.39 \\
\hline General social content & 0.29 & 0.71 \\
\hline Business and Economy & 0.21 & 0.79 \\
\hline Religion & 0.38 & 0.62 \\
\hline Political Dissidents & 0.22 & 0.78 \\
\hline Political Dissidents/Regional Militancy & 0.19 & 0.81 \\
\hline Regional Pro-Syrian Revolution & 0.38 & 0.62 \\
\hline Sports & 0.44 & 0.56 \\
\hline Cooking, Fashion, Health & 0.06 & 0.94 \\
\hline Personal Diaries & 0.20 & 0.80 \\
\hline Regional \& International Politicians \& Media & 0.56 & 0.44 \\
\hline Regional ShowBiz & 0.35 & 0.65 \\
\hline Egypt/Politics & 0.58 & 0.42 \\
\hline Kuwait/Politics & 0.73 & 0.27 \\
\hline All & 0.33 & 0.67 \\
\hline
\end{tabular}

TABLE A2: PROPORTION OF PROFILE PICTURES WITH ADULT FACES VERSUS OTHER IMAGES BY CLUSTER 


\section{NOTES}

${ }^{1}$ Bruce Etling, et. al., "Mapping the Arab Blogosphere: Politics, Culture, and Dissent," Berkman Center Publication No. 2009-06, June 2009, available at http:/ / cyber.law.harvard.edu/publications/2009/Mapping_the_Arabic_Blogosphere. ${ }^{2}$ Forthcoming Berkman study.

${ }^{3}$ Marcello Mari, “Twitter Usage Is Booming in Saudi Arabia,” GlobalWebIndex, March 20, 2013, http:/ / www.globalwebindex.net/blog/twitter-usage-is-booming-in-saudi-arabia.

${ }^{4}$ Forthcoming Berkman Center paper.

5 “4 Ways How Twitter Can Keep Growing," Peerreach Blog, November 7, 2013, http:/ / blog.peerreach.com/2013/11/4-ways-how-twitter-can-keep-growing/.

${ }^{6}$ Mari, "Twitter Usage Is Booming in Saudi Arabia," March 20, 2013, Global Web Index, http://www.globalwebindex.net/blog/twitter-usage-is-booming-in-saudi-arabia.

${ }^{7}$ Cordelia Hebblethwaite, “\#BBCtrending: Why Twitter Is So Big in Saudi Arabia," BBC, January 23, 2014, http://www.bbc.com/news/blogs-trending-25864558.

${ }^{8}$ Robert Worth, "Twitter Gives Saudi Arabia a Revolution of Its Own," New York Times, October 20, 2012, http:/ / www.nytim es.com/2012/10/21/world/middleeast/twitter-gives-saudi-arabia-a-revolution-of-its-own.html. 9 "A Virtual Revolution," The Economist, September 13, 2014, http://www.economist.com/news/middle-east-andafrica/21617064-why-so cial-media-have-greater-impact-kingdom-elsewhere-virtual.

${ }^{10}$ Marina Ottaway and Amr Hamzawy, eds., Getting to Pluralism: Political Actors in the Arab World (Washington, D.C.: Carnegie Endowment for International Peace, 2009).

11 "NGO Law Monitor: Saudi Arabia," The International Center for Not-for-Profit Law, January 18, 2015, http://www.icnl.org/research/monitor/saudiarabia.html.

12 "Internet Filtering in Saudi Arabia in 2004," OpenNet Initiative, https://opennet.net/studies/saudi.

13 "Saudi Arabia," OpenNet Initiative, August 6, 2009, https:/ / opennet.net/research/profiles/saudi-arabia.

14 "[10 proposals to protect Saudi Arabia from Twitter]," Makkah Newspaper, March 19, 2015,

http://www.makkahnewspaper.com/makkahNews/loacal/122727.html\#.VQsfK2SUfXo.

15 "[Twitter out of our control]," Al-W atan, February 13, 2013,

http:/ / www.alwatan.com.sa/culture/News_Detail.aspx? ArticleID=133168\&Catego ryID=7.

16 "Saudi Arabia: Assault on Online Expression," Human Rights Watch, November 22, 2014, http://www.hrw.org/news/2014/11/22/saudi-arabia-assault-online-expression.

17 "Saudi Arabia: Assault on Online Expression," Human Rights Watch, November 22, 2014, http://www.hrw.org/news/2014/11/22/saudi-arabia-assault-online-expression.

18 "MOI: Injunctions on Security and Ideology for Citizens and Residents, and an Extra Grace Period of 15 Days," Kingdom of Saudi Arabia, Ministry of Interior, March 9, 2014,

http://www.moi.gov.sa/wps/portal/!ut/p/b1/04_SjzQysDA3MjIyNjfTj9CPykssy0xPLMnMz0vMAfGjzOJNnQOcPS 18jQ3dA0LNDYzcE28nM28LQy8TYAKIoEKDHAARwNC-

sP1o_AqMTGGKnB2d_QwMfcxMLDwcTc18HT0CA2yDDQ2NnCEKcDjBj-P_NxU_dyoHEvPLBNFANLOGk!/dl4/d5/L2dJQSEvUUt3QS80SmtFL1o2X0dOVlMzR0gzMTBGSUUwSVFJSkozR1YzQ0w2/?WCM_GLOBA

L_CONTEXT=/wps/wam/connect/moi+diwan/moi+home+content $/$ home/news/news+archive/moi_news_08-032014a_en.

19 "Saudi Arabia: Information Requests," Twitter Transparency Report, https://transparency.twitter.com/country/sa. ${ }^{20}$ Habib Toumi, "Saudi Mufti Blasts Twitter as Evil," Gulf News, October 21, 2014, http:/ /gulfnews.com/news/gulf/saudi-arabia/saudi-mufti-blasts-twitter-as-evil-1.1401887.

${ }^{21}$ Helmi Noman, "The Use of the Internet to Enforce Religious Hegemony in Saudi Arabia," in Internet Monitor 2014: Reflections on the Digital World: Platforms, Policy, Privacy, and Public Discourse, ed. Urs Gasser, Jonathan Zittrain, Robert Faris, Rebekah Heacock Jones, Berkman Center Publication Research Publication No. 2014-17, December 15, 2014, https://thenetmonitor.org/research/2014/.

${ }^{22}$ MG Siegler, "Twitter Begins Turning on the Secure HTTPS by Default," TechCrunch, August 23, 2011, http:/ / techcrunch.com/2011/08/23/twitter-s ecure/.

${ }^{23}$ Assakina, http:/ / en.assakina.com/.

24 "[200 Saudi Twitter accounts: violence and incitement]," AlHayat, http://www.alhayat.com/Artides/7936301.

25 [Crown sponsored symposium on "social networks and social security dimensions"], http://www.mat.gov.sa/Ar/InformationTechnology/Pages/InformationSecurity/Tech-Security26051436_68.aspx 26 "[10 proposals to protect Saudi Arabia from Twitter]," Makekah Newspaper, March 19, 2015, http:/ / www.makkahnewspaper.com/makkahNews/loacal/122727.html\#.VQsfK2SUfXo. 
${ }^{27}$ Bruce Etling, John Kelly, Robert Faris, John Palfrey, "Mapping the Arabic Blogosphere: Politics and Dissent Online," New Media and Society 12 (2010): 1225-1243, doi:10.1177/1461444810385096; John Kelly et. al., "Mapping Russian

Twitter," Berkman Center Publication No. 2012-3, March 20, 2012,

https:/ / cyber.law.harvard.edu/sites/cyber.law.harvard.edu/files/Mapping_Russian_Twitter_2012.pdf.

28 http:/ / www.al-jazirah.com

29 http:/ / www.okazalyoum.com

30 http:/ / www.al-madina.com

31 http://www.alsharq.net.sa

32 http:/ / alhayat.com

33 http:/ / aawsat.com

34 http:/ / www.alarabiya.net

$35 @ N e w s \_B r k 24$, Twitter post,https://twitter.com/News_Brk24/status/557563899830992899.

36 E.g., http://www.islamacademy.net/, http://islamqa.info/, and http://www.feqhweb.com/.

${ }^{37}$ See for example@othmanalkamees, Twitter post,

https:/ twitter.com/othmanalkamees/status/631069084919070721.

${ }^{38}$ E.g., http://www.syria2011.net/, http://www.all4syria.info/.

39 http:/ /www.ibnothaimeen.com/

40 http:/ / www.binbaz.org.sa/

41 "Kingdom Will Continue to Follow Salafist Ideology: Prince Naif," Arab News, December 28, 2011,

http://www.arabnews.com/node/402266.

42 http://www.mbc.net

43 See for example Simon Owens, "Saudi Satire Ignites YouTube's Massive Growth in Middle East," U.S. News and World Report, May 30, 2012, http:/ / www.usnews.com/news/artides/2012/05/30/saudi-satire-ignites-youtubes-massivegrowth-in-middle-east; Caryle Murphy, "Young Saudis Embrace Internet Satire, Reject Wahhabism," Global Post, June 23, 2014, http:/ / www.mintpressnews.com/young-saudis-embrace-internet-satire-reject-wahhabism/192845/.

44 http://www.okaz.com.sa

45 http:/ / www.alwatan.com.sa

$46 @$ e3teqal, Twitter feed, https://twitter.com/e3teqal.

$47 @$ @LLST_ORG, Twitter feed, https://twitter.com/ALQST_ORG.

48 http://www.aljazeera.net

49 http://www.alhayat.com

${ }^{50}$ E.g., http://islamweb.net/, http://www.dd-sunnah.net/, and http://www.islammemo.cc.

51 http://www.state.gov/

52 http:/ /iipdigital.usembassy.gov

53 http:/ / www.uqn.gov.sa/

${ }^{54}$ E.g., http:/ / akhbaar24.argaam.com/, http:/ /www.an7a.com/, and http:// sabq.org/.

${ }^{55}$ E.g., http://alhayat.com/ and http://www.aljazeera.net/portal.

56 http:/ / www.ma.gov.sa

${ }^{57}$ E.g. www.sana-revo.com, www.all4syria.info, www.syria2011.net, and islamsyria.com.

$58 \mathrm{http}: / /$ arabic.rt.com

${ }^{59}$ http:/ / bambuser.com /

${ }^{60}$ Mia Shanley, "Live from Syria: Swedish Streaming Site Gains Followers," Reuters, October 2, 2012, http:/ / www.reuters.com/artide/2012/10/02/us-sweden-bambuser-idUSBRE8910D620121002.

$61 @$ alkazraj, Twitter post, https://twitter.com/alkazraj/status/502976074796367872.

$62 @$ saadalfagih, Twitter post, https://twitter.com/saadalfagih/status/568619888714981376.

$63 @$ saadalfagih, Twitter post, https:// twitter.com/saadalfagih/status/135456599631343616.

${ }^{64}$ http://www.alifta.net/Default.aspx?languagename=en

65 See for example Rulership and Shari ah-based policy

http:/ / www.alifta.net/Fatawa/FatawaChapters.aspx?languagename $=$ en $\& V i e w=$ Page $\&$ PageID $=9136 \& \mathrm{PageNo}=1 \& B$ oo $\mathrm{kID}=7$

$66 @$ aliftanet, Twitter post, https://twitter.com/aliftanet/status/615008698860068864.

$67 @$ abdullah_alweet, Twitter post,https:// twitter.com/abdullah_alweet/status/557125775137067008.

$68 @$ Dr_NoraAlsaad, Twitter post, https:// twitter.com/Dr_NoraAlsaad/status/556786484150153217.

$69 @$ aldawood1, Twitter post, https:/ / twitter.com/aldawood1/status/491326251248791552.

70 "[Through MBC family counselor calls to meet young girls and cafes to reduce spinsterhood (video)]," June 22, 2014, Twasul News, http://twasul.info/69824/. 
$71 @$ aldawood1, Twitter post, https:// twitter.com/aldawood1/status/480757652297760768

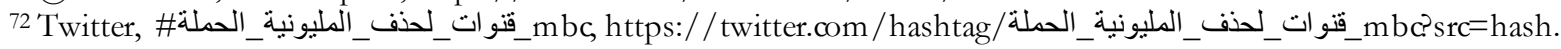

${ }^{73}$ Campaign video against MBC, https:/ / www.youtube.com/watch? $={ }_{\mathrm{zPa}}$ 9f9hMyI\#t=518.

$74 @$ h_a_m_19, Twitter post, https://twitter.com/h_a_m_19/status/484811107022819328.

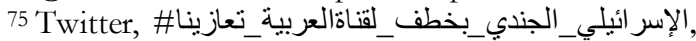

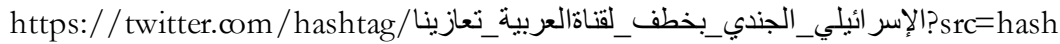

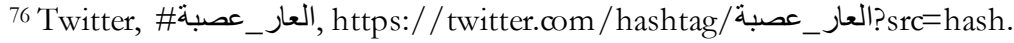

$77 @ 07 A l a z h a r e$, Twitter post, https://twitter.com/07Alazhare/status/483252995597934592.

$78 @$ @aridaa_Q, Twitter post, https:// twitter.com/Faridaa_Q/status/483219868838539264.

79 "Saudi King Congratulates Egypt's New Interim President," Al Arabiya, July 4, 2013 ,

http:/ / english.alarabiya.net/en/News/middle-east/2013/07/04/Saudi-king-congratulates-Egypt-n ew-interimpresident.html.

80 "Saudi Arabia Designates Muslim Brotherhood, ISIS, Al-Nusra Front terrorist organizations," Asharq Al-Awsat, March 7, 2014, http:/ /www.aawsat.net/2014/03/artide55329786.

81 "Mapping the Global Muslim Population," Pew Research Center, October 7, 2009,

http://www.pewforum.org/2009/10/07/mapping-the-global-muslim-population/.

82 Forthcoming Berkman Center study.

83 "Flogging of Raif Badawi in Saudi Arabia 'vicious act of cruelty," Amnesty International, January 9, 2015,

https://www.amnesty.org/en/press-releases/2015/01/ flogging-raif-badawi-saudi-arabia-vicious-act-cruelty/. $84 @$ @AlprqAsari, Twitter post, https://twitter.com/AlprqAsari/status/555496102527389697.

85 “Saudi's ‘to Review’ Flogging of Blogger Raif Badawi," British Broadcasting Corporation, January 16, 2015, http://www.bbc.com/news/world-middle-east-30856403.

$86 @$ gsthnin, Twitter post, https://twitter.com/gsthnin/status/556144535646904320.

$87 @$ @_a_aldweesh, Twitter post, https:// twitter.com/s_a_aldweesh/status / 554239093932953601.

$88 @$ khalaf_h, Twitter post, https://twitter.com//status/552823113910460416; Twitter post, https://twitter.com/khalaf_h/status/552823113910460416.

$89 @$ m7hamm9d, Twitter post, https:// twitter.com/m7hamm9d/status/554366228047749120.

$90 @$ oamaz7, Twitter post, https:// twitter.com/oamaz7/status/554353966889574400.

$91 @$ Altmimy_1, Twitter post, https://twitter.com/Altmimy_1/status/555103676696506368.

$92 @$ mohamdalbarrak, Twitter post, https: / / twitter.com/moham dalbarrak/status / 554593282203074560.

93 "President Hadi Leaves Yemen as Saudi-Led Raids Continue," BBC, March 27, 2015,

http://www.bbc.com/news/world-middle-east-32078817.

94 Ken Dilanian, "Saudis Begin Airstrikes Against Houthi Rebels in Yemen," Yahoo! News, March 25, 2015, http:/ / news.yahoo.com / fall-yem en-government-leaves-us-few-options-183533025--politics.html.

95 “[\#decisive_storm hashtag first in Arab region and second globally]," Al Jazeera, Mary 27, 2015,

http://mubasher.aljazeera.net/news/2015/03/201532783550140351.htm.

${ }^{96}$ For background on the origin and meaning of these terms see: Aaron Y. Zelin and Phillip Smyth, "The Vocabulary of Sectarianism," Foreign Policy, January 29, 2014, http:/ foreignpolicy.com/2014/01/29/the-vocabulary-of-s ecta rianism/.

$97 @$ naseralomar, Twitter post, https://twitter.com/naseralomar/status/580996732651094016.

$98 @$ dr_alghfaily, Twitter post, https://twitter.com/dr_alghfaily/status/580663804201046016.

$99 @$ assdais, Twitter post, https://twitter.com/assdais/status/581016025178603521.

$100 @$ oao50, Twitter post, https:// twitter.com/oao50/status/582138150069407744.

$101 @$ e3teqal, Twitter post, https://twitter.com/e3teqal/status/585841575453970432.

$102 @$ e3teqal, Twitter post, https://twitter.com/e3teqal/status/581085309099753472.

$103 @$ i3tesaaam, Twitter post, https://twitter.com/i3tesaaam/status/582850377990709248.

$104 @$ Sama7ti, Twitter post, https://twitter.com/Sama7ti/status/585925846013054976. 